\title{
Women, Medieval Commerce, and the Education Gender Gap ${ }^{\#}$
}

\author{
Graziella Bertocchi* \\ Monica Bozzano**
}

September 2015

\begin{abstract}
\# We thank two anonymous referees, Erich Battistin, Giorgio Brunello, Davide Cantoni, Renato Giannetti, Andrea Ichino, Marco Percoco, Paola Profeta, and seminar participants at the 2013 Economic History Society Annual Conference, XI Brucchi Luchino Labour Economics Workshop, 2013 BOMOPAV Meetings, 17th International Society for New Institutional Economics, 2014 Sheffield Workshop in Macroeconomics, PRIN Workshop on Institutions, Social Dynamics and Economic Development, 2015 Bocconi-ASSI Young Researchers Day, 2015 Pisa Economic History Workshop, and Universities of Pavia, Modena and Oslo for helpful comments. Generous financial support from Fondazione Cassa Risparmio di Modena, University of Modena and Reggio Emilia and the Italian University Ministry is gratefully acknowledged.
\end{abstract}

*Corresponding author. University of Modena and Reggio Emilia, CEPR and IZA. Address: Dipartimento di Economia Marco Biagi, Viale Berengario 51, 41121 Modena, Italy, e-mail graziella.bertocchi@unimore.it, phone+390592056856, fax +390592056947.

**University of Modena and Reggio Emilia. Address: Dipartimento di Economia Marco Biagi, Viale Berengario 51, 41121 Modena, Italy, e-mail monica.bozzano@unimore.it. 


\begin{abstract}
We investigate the historical determinants of the education gender gap in Italy in the late nineteenth century, immediately following the country's Unification. We use a comprehensive newly-assembled database including 69 provinces over twenty-year sub-samples covering the 18611901 period. We find robust evidence that in 1861, at Unification, gender equality in education is still positively associated with the medieval pattern of commerce, along the routes that connected Italian cities among themselves and with the rest of the world. The beneficial effect of medieval commerce on female education relative to male persists after we control for a broad set of confounding factors reflecting the geographic, economic, political, and cultural differentiation of medieval Italy. The long-term influence of medieval commerce dissipates only gradually after nationally-directed educational policies are implemented after Unification. This is consistent with the hypothesis that its transmission occurs through slow-changing cultural beliefs, as confirmed by further suggestive evidence of its influence on contemporary outcomes related to gender and family culture.
\end{abstract}

JEL CODES: E02, H75, I25, J16, N33, O15.

KEYWORDS: Education gender gap, medieval commerce, culture, Italian Unification, institutions. 


\section{Introduction}

The reversal of the education gender gap, to the advantage of women, has been part of a quiet revolution which has gradually transformed women's lives in the vast majority of OECD countries (Goldin, 2006). To understand the drivers of this change is tantamount to understand the reasons for the previous, long-standing inferior condition of women. Gender inequality is a multifaceted phenomenon that, beside education, requires consideration of its economic and political dimensions. ${ }^{1}$ Historically, the gender gap in wages and labor force participation has been even deeper than that in education, ${ }^{2}$ not to mention the fact that less than a century ago in most OECD countries women were not even granted the most elementary political right, i.e., the right to vote. ${ }^{3}$ However, even if the education gender gap only captures the tip of the iceberg, to understand its empirical determinants and its evolution would still represent a crucial advancement which we try to achieve in this paper.

We start by assembling a new dataset that covers a sample of Italian provinces in the 1861-1901 period, i.e., the initial forty years after the country's Unification, a time that still witnessed a sizeable gender gap even at the primary school level. The main hypothesis we test over these data is that, at Unification in 1861, the education gender gap is still influenced by the medieval pattern of commerce, along the routes that connected Italian cities among themselves and with the rest of the world, with a more favourable female position in the provinces that were commercial centers in the late Middle Ages.

Between the end of the thirteenth century and the fourteenth century, Italy was at the center of an active process of expansion of trade, city growth, and economic and social development. This period was in fact characterized by an intensification of international exchange throughout Europe and with the progress of mercantile science and practices. These developments implied the necessity for merchants to acquire considerable skills in arithmetic, bookkeeping, reading, and writing. In a context where women's education was generally neglected, merchant communities were characterized by the fact that women, being often in charge of business operations during their men's years-lasting travels, needed to become economically active and, therefore, literate. The fact that in Italian commercial centers women enjoyed a privileged condition is put forward by a vast historical literature.

Back in medieval Italy, the effect of trade on the promotion of women's education run through two parallel and mutually reinforcing channels that reflected fundamental economic incentives: on the one hand, a transfer of duties from men to women was facilitated by the fact that, contrary to other occupations, commerce did not require physical strength; on the other, the physical absence of men forced women to take charge. Both factors contributed to generate a special attention to girls'

\footnotetext{
${ }^{1}$ Hausmann et al. (2007) present the components of the Global Gender Gap Index and Bozzano (2014) adapts them to contemporaneous Italian data.

${ }^{2}$ Goldin (2006) traces an economic history of the transformation of American women's status in employment and education and shows that the gender gap in college education has been narrower than the gender gap in labor force participation.

${ }^{3}$ Bertocchi (2011) and Braun and Kvasnicka(2013) study the historical process of women's enfranchisement.
} 
education within merchant communities. Our hypothesis is that, over the next centuries, this original form of gender equality bred the development of a system of beliefs and cultural norms which persistently affected the societal value assigned to the education of women. In particular, commercial centers developed the belief that women were worth receiving more education, and this cultural attitude persisted even after the fundamentals that had determined its economic premises ceased to exist, with the decline of Italy as a major commercial hub. Thus, the shift in cultural values generated by medieval trade - reinforced by the fact that women found themselves entrusted not only of trade, but also of children's education - persistently changed the role of women in society and perpetuated its original influence on women's education through the intergenerational transmission of the acquired skills, role models, and beliefs. As a result of this long-term development, at Unification in 1861 we observe more equal educational attainment for girls in provinces that hosted a trade center in the Middle Ages.

Our dataset also allows us to analyze the crucial time span for Italian history that follows Unification. The historiography of the 1861-1901 period we focus on reports a decline of the gender differential in primary school enrollment rates from 12.5 to about 5 percentage points, ${ }^{4}$ reflecting a process of gender equalization and convergence across pre-unitary states. However, our analysis shows that the influence of medieval commerce dissipates only gradually after nationally-directed education policies are implemented, suggesting that beliefs underlying gender equality embeds a deeply-rooted, cultural nature.

In more detail, we perform our empirical investigation as follows. Our main dependent variable is a provincial measure of gender equality given by the ratio of female to male enrollment rates in upper primary school which, contrary to lower primary, was not compulsory. Medieval commerce is a dummy variable that takes value 1 if the main town in the province was a commercial hub in late Middle Ages and 0 otherwise. Over a cross section of provinces taken at Unification, we also control for a broad set of observable and potentially confounding factors. We consider five main sets of alternative historical determinants of gender equality in education: the geographic characteristics of the provincial territories; the level of prosperity, as captured by a measure of urban population density in 1300; the establishment of an ancient university; the fourteenth-century political regimes; and the prevailing medieval family type. Even after controlling for all the above historical correlates, as well as proxies for the contemporaneous level of development, we find that after several centuries medieval commerce is strongly and persistently affecting gender equality in education in 1861.

Our findings are robust to a number of alternative specifications involving variants of dependent variables, regressors, samples, and estimation techniques including 2SLS. Moreover, we find that medieval commerce exerts no significant influence on the level of schooling itself, which underscores its peculiar influence only through gendered human capital accumulation. Finally, the effect of medieval commerce is declining but persistent over our sample, consistently with evidence of convergence across Italian provinces after Unification. This trend can be interpreted in light of

\footnotetext{
${ }^{4}$ These figures refer to census data at the regional level reported by A'Hearn et al. (2011, fig. 5.9, p. 185).
} 
the distinction (suggested by Roland, 2004) between slow-moving and fast-moving institutions. Cultural beliefs are a leading example of the former, while political institutions exemplify the latter. In our context, cultural beliefs regarding gender roles along the education dimension are indeed highly persistent over nearly six centuries, at least up to Unification. At the same time, Unification represents a sudden change of the political and institutional environment involving the implementation of national educational policies - starting with compulsory primary education for boys and girls - which drive convergence to a lesser gap. However, convergence is far from immediate, and it takes four decades for the influence of medieval trade to vanish, which suggests that its transmission occurs through deeply-rooted, slow-changing cultural beliefs, rather than by persistence of institutions or economic incentives. Further evidence on the diffusion of abacus schools up to the Renaissance and on contemporary indicators of gender and family culture confirms this interpretation.

To sum up, our finding that gender equality in education is persistently influenced by the medieval pattern of commerce might be explained by alternative channels of transmission: unvarying fundamental economic incentives, institutional legacy, or cultural beliefs. As previously suggested, our hypothesis is that cultural beliefs represent the main channel. Moreover, we can rule out the first channel since, after the end of the Middle Ages, Italy entered a period of gradual economic decline that persisted until the middle of the nineteenth century, erasing the crucial importance of the initial fundamentals linked to medieval commerce. We can also rule out the second channel, since between the Middle Ages and Unification Italy was characterized by complex political and institutional developments, shifting from the communal era to the onset of pre-unitary nation-states, going through the Spanish and Austrian dominations first, to the Napoleonic disruption next, and finally to the new balance of powers established with the Restoration.

Among the papers that have focused on the education gender gap the one by Becker and Wößmann (2008) is the closest to our approach since they investigate the determinants of girls' education by looking at sub-regional nineteenth-century data within Prussia. While their focal variable is the spread of Protestantism, with its stress on the study of the Bible both for boys and girls, a connection with our findings comes from the coincidence, noticed for instance by Spufford (1995), between the high literacy rates in Protestant regions and their commercial success. Arruñada (2010) suggests that the relative economic success of Protestantism should be attributed to its ability to promote a social ethic that facilitates trade. In other words, a similarity emerges between the role of Protestantism and the role of commerce as far as the development of women's education is concerned. ${ }^{5}$ The attention to the determinants of women's education in the nineteenth century - a time of broad social transformation in Western Europe - is witnessed by additional contributions by Perrin (2014) and Beltrán Tapia and Martínez-Galarraga (2015), who respectively focus on France and Spain. Furthermore, for a sample of African countries, Nunn (2014) finds a positive influence of the Protestant missions established during the colonial period on the current education level of females.

\footnotetext{
${ }^{5}$ Protestantism was totally absent in Italy throughout the period under examination.
} 
The literature on girls' education also includes Goldin (1998) and Goldin et al. (2006), who study the post-World War I evolution of secondary and tertiary education, respectively, for American women. Fernandez and Wong (2011) model the determinants of the recent disappearance of the education gender gap in the US, by linking it to economic and social developments. Bertocchi et al. (2014) document a similar trend for Italy, with a reversal of the education gender gap in the postWorld War II period. Lagerlöf (2003) provides a model of the evolution of the gender gap in human capital. The channels that we suggest to understand the effect of medieval commerce on the position of women in society have been recognized, in different contexts, in related streams of the literature. For instance, the influence of women's inferior physical strength on human capital accumulation is modeled by Galor and Weil (1996). A similar argument is advanced by Alesina et al. (2013) to test Boserup's (1970) hypothesis that plough (rather than shifting) cultivation determined the historical gender division of labor, ${ }^{6}$ and by Xue (2015), who shows that historical textile production has a persistent impact on gender roles in contemporary China. ${ }^{7}$ The impact on women's labor force participation of men's absence - as the result of war - is studied by Duby and Perrot (1998), Goldin (1991), Acemoglu et al. (2004), Goldin and Olivetti (2013), and Doepke et al. (2015). The role of mothers' education on children's outcomes is stressed by Schultz (2002) and Doepke and Tertilt (2009), while Fogli and Veldkamp (2011) and Fernandez (2013) explore the implications of the associated cultural change. ${ }^{8}$

The rest of the paper is organized as follows. In Section 2 we document the peculiar role of women within merchant communities in medieval Italy. In Section 3 we briefly describe the education system in Italy before and after Unification. In Section 4 we present our newly-collected dataset on enrollment by gender at the primary school level in 1861-1901. Section 5 contains the main results. In Section 6 we present robustness checks and extensions. Section 7 is devoted to alternative outcomes, other than the education gap at Unification, that are linked with medieval commerce. We conclude with Section 8 .

\section{Women and trade in medieval Italy}

Between the end of the thirteenth century and the fourteenth century, Italy was at the center of an active process of expansion of trade, city growth, and economic and social development. This period, which is referred to as the "heroic era of the merchant" (Sapori, 1972), was in fact characterized by an intensification of international exchange throughout Europe which was in turn associated with the progress of mercantile science and practices, such as banking, payment tools, marine insurance, as well as mercantile laws and bookkeeping techniques (Gibbins, 1891). These developments implied the necessity, for merchants, not only to reach a basic level of literacy but also to acquire considerable skills in arithmetic, bookkeeping, reading, and writing. One of the consequences was the establishment of abacus schools, i.e., schools with a commerce-directed

\footnotetext{
${ }^{6}$ Since the plough system applied to the entire territory of Italy, we cannot impute to this channel regional differences in women's outcomes.

${ }^{7}$ In a different but related context Bøler et al. (2015) show that globalization tends to reduce the gender wage gap by exposing exporters to higher competition.

${ }^{8}$ For the more general influence of medieval trade see Cantoni and Yuchtman (2014) and Boerner and Severgnini (2012).
} 
curriculum that placed special emphasis on mathematics, as well as other disciplines useful for trade. This curriculum represented an important innovation with respect to the then predominant grammar-school model, which was mainly oriented toward the study of Latin and the classics. Abacus schools were created by wealthy merchants, with the support of communal authorities, in order to train their sons to take over the family business (Grendler, 1989). However, girls were also admitted to abacus schools, since in merchant families women were frequently in charge of business operations. In fact, within merchant communities, women quickly acquired a special role, since during the men's years-lasting travels, their wives, mothers, sisters, and daughters often needed to become literate in order to run the family business (Ricci, 2011). This peculiar position of women in merchant communities is amply documented. The Florentine banker Giovanni Villani reports that in Florence in the early thirteenth century there were between 8,000 and 10,000 "boys and girls" learning to read (Sapori, 1972). In the middle of the fourteenth century Boccaccio's Decameron narrates of a merchant from Genoa who praises his wife, Zinevra Lomellini, for her ability to write, read, and count "as well as a merchant".

Additional evidence on the role of women within trading communities during the Middle Ages comes from a literature based on female epistolary writing. These noticeable examples of literate and highly active women invariably come from cities and towns that were involved in commerce (Palermo, 2010; Miglio, 2008). For instance, we can report the case of Margherita Datini, from Prato and Florence: "In Margherita's merchant world, letter writing was a major concern, and her household duties included frequent reports to her absent husband" (Crabb, 2007). Her correspondence with her husband is indeed an example of adaptation of the mercantile letter, a genre of epistolary writing which represented a crucial tool for business operations. In her writings she reported everyday's concerns but also her involvement with her husband's economic and political activities (Byrne, 1996). Another example is Alessandra Strozzi from Florence, whose letters reveal her direct participation in trade as well as in the social and political life of the city of Florence (Doni Garfagnini, 1999).

Evidence of women being literate and actively participating in economic activities is also reported for other Italian commercial centers, such as Venice, Genoa, Palermo, Bari, and Siena. In Genoa, as well as in Florence, women were even investing in the merchant trading companies (Wiesner, 2000). In early thirteenth-century Venice Guglielma Venier, during her husband's absence, took care of the family estate and personally recorded commercial transactions, a task which clearly required an ability to write and count (Ricci, 2011). In the town of Barletta, located within the commercial hub of Bari in Apulia, the presence of women merchants is reported as early as 1280, when the king asks their advice in order to assess the market value of his stock of commodities, while in 1330 another woman, Ferella de Pietrozeczo, is involved in sophisticated ventures involving the commerce of spices (Diviccaro, 1999). The role of women in commerce is documented as early as between the tenth and the twelfth centuries in Amalfi, near Naples, which having been a maritime republic witnessed a much earlier development of trade, again associated with the emergence of new economic opportunities for women (Skinner, 2004). ${ }^{9}$

\footnotetext{
${ }^{9}$ While guilds played a major role in early European development, there is no evidence that their presence was beneficial for women's education. According to Ogilvie (2014), across pre-industrial Europe guilds were male-
} 
A similar association between trade and women's education is found also outside of Italy. Using sources represented again by letters, diaries, and contracts, Uitz (1990) describes the growth of new urban centers across Europe between the twelfth and the fourteenth centuries and stresses how trade radically changed women's lives, by creating new opportunities that were later reflected in widespread changes in the laws regulating women's economic rights. Richardson (1997) illustrates the peculiar position of women in trade in medieval England, again on the basis of their commercial writings. In a subsequent phase, the commercial necessity of literacy is also emphasized by Spufford (1995) and invoked by Hoftijzer (2001) in order to explain the relatively high female literacy rates in Amsterdam during the seventeenth century.

\section{The school system in Italy at Unification}

The purpose of this section is to provide a description of the school system in Italy immediately before and after Unification, up until the beginning of the twentieth century. ${ }^{10}$

The period immediately preceding Unification, often referred to as Risorgimento, runs from the end of the Napoleonic era in 1815 until 1871 (when Rome becomes the capital). The Unification of Italy represents a key event in the geopolitics of Europe (Dincecco et al., 2011). Before this historical turning point Italy was divided among four main dynasties: the Savoys, ruling in the North West, i.e., in Piedmont, Liguria, and Sardinia; the Habsburgs, holding direct control over the LombardyVenetia in the North East, as part of the Austrian Empire, as well as indirect control over the Granduchy of Tuscany and other minor Duchies nearby; the Pope, reigning over Rome and the Center South; and the Bourbons, in charge of the South and the Duchy of Lucca.

The pervasive regional differentiation in the institutional and cultural background inherited from Risorgimento represents the initial condition over which the Kingdom of Italy is established. Preunitary states presented deep differences along several dimensions, including literacy and schooling attainment, partially as a consequence of educational policies (A'Hearn et al., 2011). For instance, if in Lombardy-Venetia schooling was compulsory until age 12 and the Kingdom of Sardinia implemented a long-term plan to regulate the educational system, in the Papal and Bourbons' territories no such policies were present. In some areas of the peninsula there was not even a minimum of what primary school ought to transmit to pupils: rather than being concerned with reading, writing, and the first notions of maths, in many cases it reduced to religion and, for girls, knitting and sewing. ${ }^{11}$ In other cases teachers were illiterate. ${ }^{12}$ Female education was largely neglected (Serristori, 1842) in most areas, with the exception of Lombardy, Rome, and the Duchy

\footnotetext{
dominated and restricted the access of women to training. Moreover, even though merchants were often guilded, guilds were most prevalent in manufacturing among craftsmen and artisans.

${ }^{10}$ For further details see Vigo, 1971; Bertocchi and Spagat, 1997; Zamagni, 2002; A'Hearn et al., 2011; Bertola and Sestito, 2013.

${ }^{11}$ The so-called "lavori donneschi", i.e., "women's work", continued to be one of the main subjects taught in upper primary schools to girls compared to geometry and technical drawing for boys (Incatasciato, 1978). This gendered distinction in the content of schooling was abrogated only after World War II.

${ }^{12}$ In the Bourbons' territories the law explicitly allowed the hiring of illiterate female teachers (De Mauro, 1963, p. 39). 
of Parma and Piacenza (Vigo, 1971). In the eve of Unification only 27 percent of the adult population, that is only 5 over 22 millions of Italians, were able to read. Only Piedmont and Lombardy showed literacy rates over 40 percent in line with neighbouring countries (A'Hearn et al., 2011).

In an international perspective, late nineteenth-century Italy - with 77 girls over 100 boys enrolled in primary school - outperforms Spain (60), equals the Netherlands (78), but lags behind most other countries, starting with Great Britain (95), Belgium (94), and Prussia (92). ${ }^{13}$ At the beginning of the period under investigation the average literacy rate is 23 percent, while the male one is 30 percent against 16 percent for females, with a differential of 14 percentage points. According to Cipolla (1969), this is lower than in Spain (21) but twice that of France (7) and Prussia (5).

At Unification the Kingdom of Italy implemented national educational policies primarily aimed at removing regional disparities across regions. In 1859, even before Rome became the capital, the Casati Law disciplined the school system of the new polity. The main innovation was the imposition of free and compulsory primary education for boys and girls, starting at age 6 . The law introduced an initial compulsory two-year lower primary school (extended to three years in 1877 by the Coppino Law) followed by a subsequent non compulsory two-year upper primary. The Casati Law was explicitly inspired by the Prussian system of nationally directed education. The presence of free schools for boys and girls was made mandatory for the local authorities, in the effort to erase the regional differences inherited from the pre-unitary polities and the differential supply and quality of primary schools. Even though ultimately these policies proved effective and contributed to a substantial decline, together with a regional convergence, of the gender gap in education by the end of the nineteenth century, the legal provisions were enforced only slowly and unevenly. It is only with the Giolitti Age in 1904, i.e., outside our sample period, that mandatory education for twelve years was introduced with the Orlando Law.

\section{Data and descriptive statistics}

In order to study the long-term determinants of gender equality in education, we compile a database on education outcomes in late nineteenth-century Italy drawing from various sources. The main source is represented by data collected by the Italian Ministry of Agriculture, Industry and Commerce (MAIC, several years). Our data cover 69 Italian provinces (at 1871 boundaries). Even though most of our analysis focuses on year 1861, we collect information about three points in time (1861, 1881, and 1901), spanning the initial forty years of the unified Kingdom of Italy.

It should be stressed that enrollment data at the provincial level are only available until 1901, and that data collection at this level of disaggregation is resumed only after World War II. To our knowledge, this is the first time that these early provincial data are employed in econometric analyses.

\footnotetext{
${ }^{13}$ The source is MAIC (1864).
} 
For our dependent variables, we collect enrollment rates by gender for the population of primary school age, which consists of the population between 6 and 12 (excluded) years of age. On this basis we calculate a measure of gender equality given by the female to male ratio in enrollment rates. This measure is equivalent to the UN definition of the Gender Parity Index, where 0 corresponds to extreme inequality and 1 to full equality. While our focal variable refers to such ratio for the non compulsory upper primary level, for the sake of comparison we also keep track of it for the lower and aggregate primary levels. ${ }^{14}$ Beside data by gender, we also include general indicators of schooling defined as the number of pupils enrolled in primary school over the number of children of the corresponding 6-12 school age, again available at the upper, lower, and aggregate primary levels. ${ }^{15}$

Figure 1. Medieval commercial routes in Europe

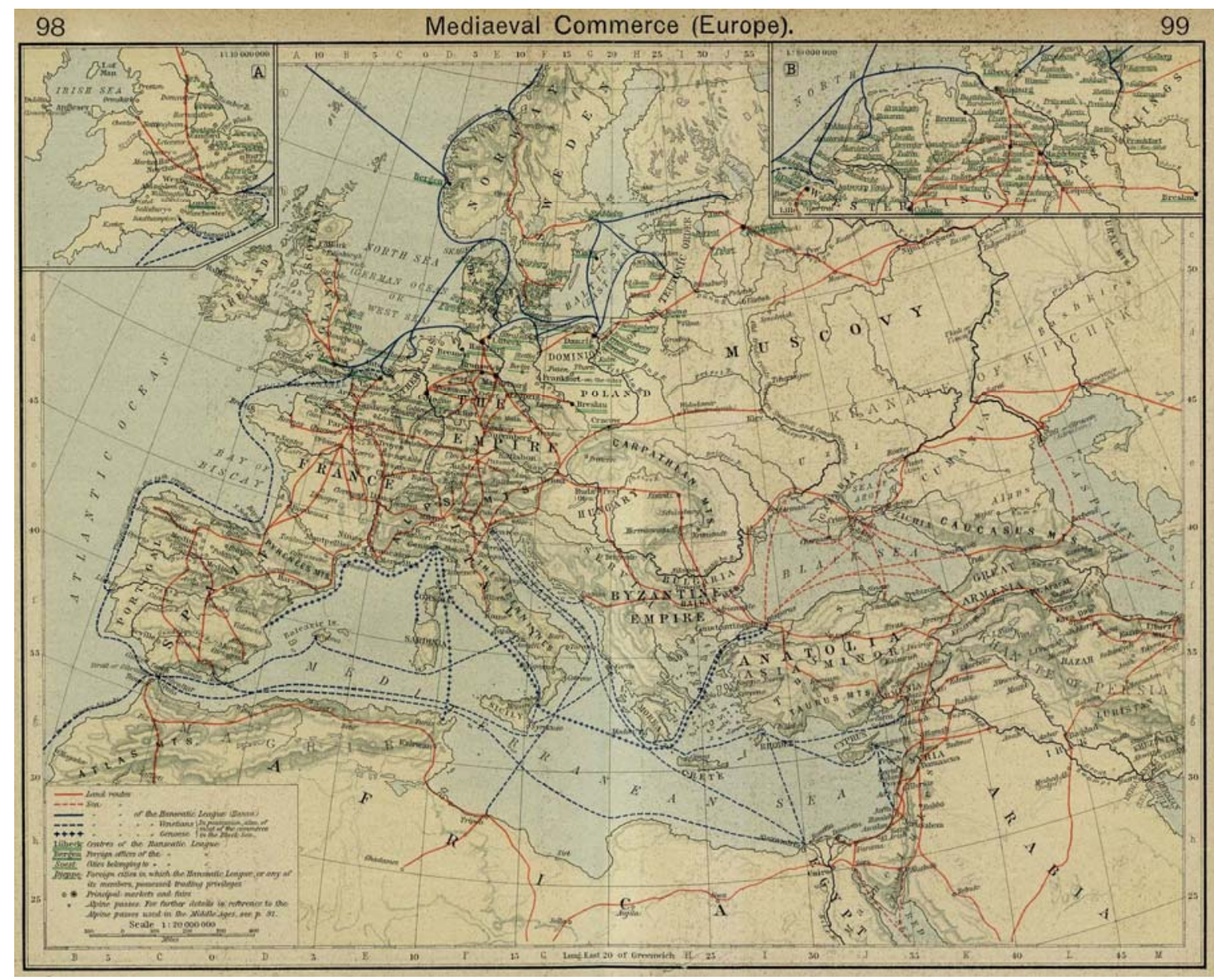

Source: Shepherd (1926).

To detect the potential role played by history, and in particular the influence of medieval commerce, we create a province-level indicator dating back to the Middle Ages. Italy was an important fulcrum

\footnotetext{
${ }^{14}$ The lower level consisted of two years of schooling, extended to three after 1877; the upper level consisted of two years (see Section 3). Because of lack of data at the provincial level, the denominators of the enrollment rates at the upper and lower levels are always the corresponding 6-12 population figures.

${ }^{15}$ In Sub-section 6.4 we introduce additional proxy measures of the gender gap in education.
} 
of international exchange in the period under consideration due to its strategic position at the crossroads between North-western Europe and the Levant. However not all territories were equally involved. Figure 1 provides a visual illustration of the pattern of medieval commercial routes in Europe.

Figure 2. Italian provinces hosting a medieval commercial center

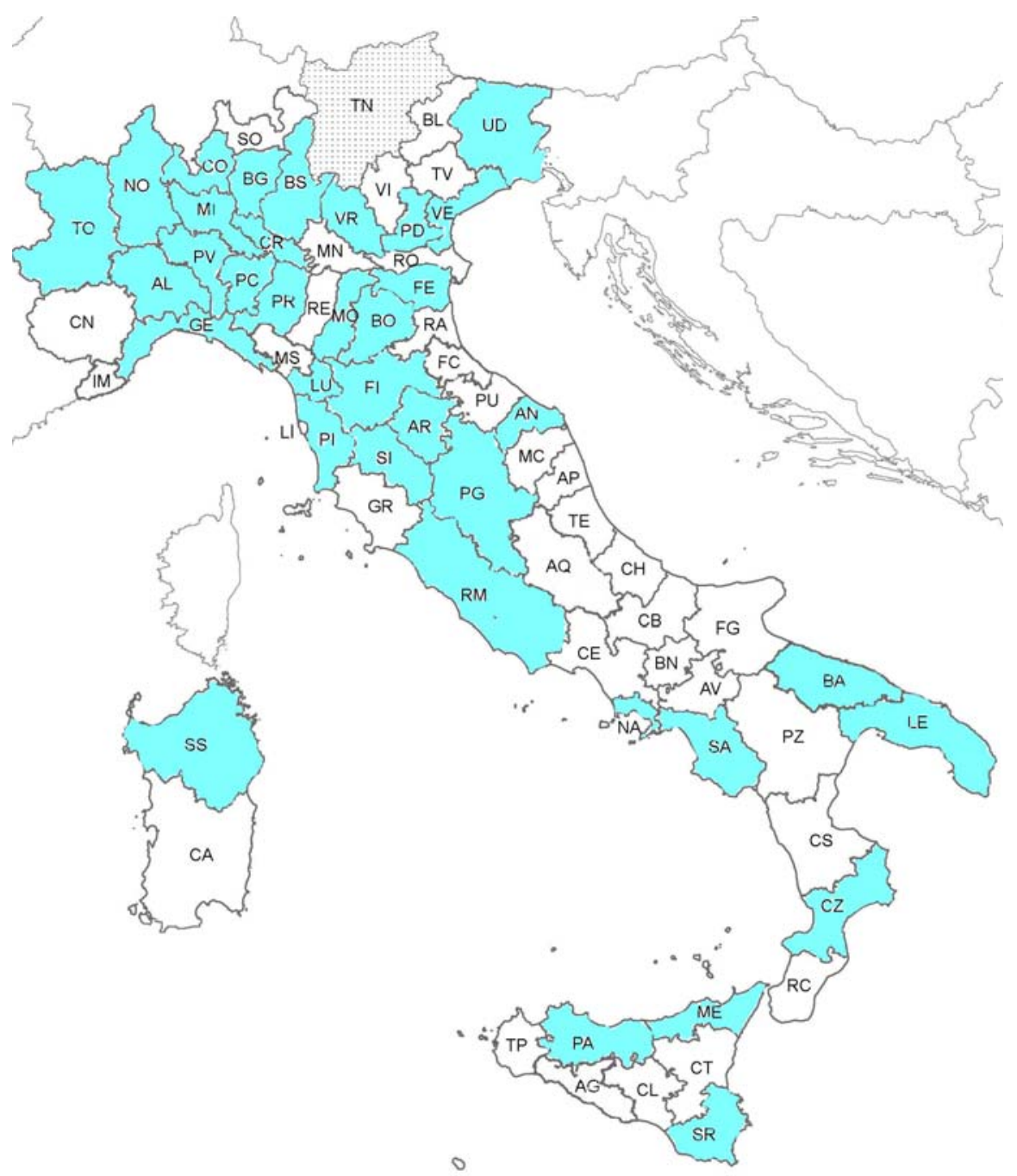

Source: We match medieval commercial centers with Italian provinces (at 1871 boundaries). Provinces containing a medieval commercial center are shaded. Provinces are identified by abbreviations of current provincial names. See the Appendix for sources.

Our measure of the influence of medieval commerce in Italy is coded as a dummy variable that takes value 1 if the main town in the corresponding Italian province was on a trade route, and/or a fair site, and/or the seat of a banking institution in late Middle Ages, and 0 otherwise. ${ }^{16}$ Out of the 69 provinces in our sample, 36 are classified as commercial centers. The map in Figure 2 highlights

\footnotetext{
${ }^{16}$ We refer to the Appendix for more detail on the definitions and sources we employ.
} 
commercial centers. Beside former maritime republics such as Genoa, Venice, and Pisa, the list includes, for instance, Verona and Ancona, which were hosting trading fairs, as well as Florence and Milan, as important banking centers. The South was also well represented, with important trading centers such as, for example, Naples, Palermo, Messina, Syracuse, and Bari.

We also collect data on additional indicators that may suggest alternative long-term determinants of human capital accumulation and its gendered dimension. Beside medieval commerce, we evaluate five potentially confounding factors.

First, we consider a set of geographic controls reflecting factor endowment and including latitude, longitude, access to sea, access to navigable river, ${ }^{17}$ and the prevalence of plain surface in the provincial territory.

Second, as a proxy of prosperity, we include urban population density, defined as the size of total urban population in 1300 in each province divided by the provincial surface. ${ }^{18}$

Third, to capture the potential influence of the broader medieval cultural environment, we construct a dummy variable for the establishment of a university between the eleventh and the thirteenth century, i.e., prior to the expansion of trade. ${ }^{19}$

Fourth, to detect the potential role played by the family in the transmission of gender norms, we include a set of dummy variables reflecting the prevailing family type in the Middle Ages in each province. In order to code these variables we build on the contribution of Todd (1990), who distinguishes for the Italian peninsula three family types: incomplete stem, communitarian, and egalitarian nuclear. ${ }^{20}$ However, following Del Panta et al. (1996) who specifically focus on Italy, we augment Todd's classification to distinguish between two different models of egalitarian nuclear family, which are respectively associated with delayed and early marriage age for women. ${ }^{21}$ As a result, we obtain a set of four dummy variables. ${ }^{22}$

\footnotetext{
${ }^{17}$ On the influence of ports on Italian cities over the 1300-1861 period see Bosker et al. (2008).

${ }^{18}$ The numerator is taken from Malanima (1998), who provides estimates of the populations of Italian cities with more than 5,000 inhabitants in 1300. To be noted is that, as in Cantoni (2015), in each province there may be more than one city, to capture the fact that in some provinces urban population increased through the creation of new, smaller centers rather than through the expansion of a single one.

${ }^{19}$ For a review of the history of medieval universities see Rashdall (1987). See also Percoco (2014) and Cantoni and Yuchtman (2014) on the influence of universities on development, in Italy and Germany respectively.

${ }^{20}$ Todd's classification is organized along two leading axes, residential habits after marriage and inheritance rules: in egalitarian nuclear families children leave after marriage and equal partition applies; children stay on with their parents in incomplete stems and communitarian families, while they are respectively characterized by primogeniture and partition. To determine the distribution of family types in Europe Todd starts from the patterns documented for the 1950s and 1960s on the basis of censuses and from those he collects information back to the Middle Ages. As shown by Galasso and Profeta (2011), Todd's classification is consistent with the measure of family ties proposed by Alesina and Giuliano (2010). See also Bertocchi and Bozzano (2015) on the influence of family types on the education gap.

${ }^{21}$ Marriage age is a significant indicator of the degree of subordination of women with respect to men and therefore of gender inequality.

${ }^{22}$ In a European perspective, Todd's classification is employed by Duranton et al. (2009) to study the effect of family structure on various economic outcomes (labor force participation, employment in manufacturing and services, GDP per capita, Gini coefficients) and by Galasso and Profeta (2011) to study pension systems and redistributive policies.
} 
Fifth, to control for the legacy of deeply-rooted political institutions that may have shaped educational policies and the evolution and persistence of gender disparities, we construct a set of dummies for the prevailing political regimes during the fourteenth century: namely, the Signorie, the Communal republics, the Papal State, the Kingdom of Sicily, and peripheral areas. ${ }^{23}$

Lastly, to find a source of exogenous variation in medieval commerce we collect data on the presence of a town in Italy in year 1000 and we code a dummy variable for the presence of a town in year 1000 building on the information contained in Bairoch et al. (1988), who report the size of European cities that ever reached 5,000 inhabitants over the period 800-1850 (the 13 cities reported for year 1000 actually all had more than 10,000 inhabitants). The dummy takes value 1 if in year 1000 there existed a town within each province's surface and 0 otherwise.

While all of the above reflect historical factors, we also collect contemporaneous correlates of economic development, for each year in our sample. We use two proxy measures of the level of wealth. The first is the average height of conscripts aged 20. Data on average height for the three waves are taken from A'Hearn et al. (2009). Height is often employed in the economic history literature because it provides researchers with a measure of the stock of nutritional investment and therefore important indirect information on changes in the well-being of populations (Fogel et al., 1982; A'Hearn and Vecchi, 2011). However, since the available data neglect female stature, whose trend does not necessarily mimic that of males, as an additional proxy for wealth we also consider contemporaneous population density (data are from the census). Furthermore, we control for the degree of structural transformation using an index of industrialization computed by Ciccarelli and Fenoaltea (2013) as the share of value added in manufacturing (excluding construction) over the share of the male population over age 15 (data are from census).

Finally, we consider factors related to the supply of schooling and school quality, which we proxy with the number of children (aged 6-10) per school, the number of children (aged 6-12) per teacher, the number of pupils per teacher, and the fraction of female teachers in primary public schools. The first variable, taken from Buonazia (1870), refers to the number of schools in 1869, divided by the number of children in 1870. The other variables are measured in 1862-63 and taken from MAIC (1865) and Vigo (1971).

More details on the definitions and sources of all variables, as well as on methodological issues, can be found in the Appendix.

Our dataset generates a set of stylized facts that can suggest preliminary hypotheses and considerations. The descriptive statistics reported in Table A2 for the 1861 cross section reveal that in primary schools in the aggregate the average enrollment rate is 39.5 percent and the average female to male enrollment ratio is 0.71 (where 1 represents perfect equality). However there exists significant variation across provinces for both outcomes, ranging from 9.8 to 117.3 percent for the

\footnotetext{
${ }^{23}$ This classification is from De Blasio and Nuzzo (2010).
} 
enrollment rate ${ }^{24}$ and from 0.06 to 1.52 for the female to male enrollment ratio. ${ }^{25}$ Moreover, the picture changes considerably if one distinguishes between the lower and upper primary level, which justifies our focus on the non mandatory upper level as the main indicator of gender equality in education.

The map in Figure 3 reports the female to male ratio of the enrollment rates at the upper primary level by province in 1861. Data are organized by quartiles. The darker is the shade of the provincial surface, the larger the female to male ratio. The map confirms the differentiation across provinces. For the subsequent years in the sample, gender disparity will remain more pronounced at the upper level, despite a general gradual closing of the gender gap. Nevertheless, for the last year of the sample differences between boys and girls are far from eradicated.

Figure 3: Gender equality in education, Italy 1861

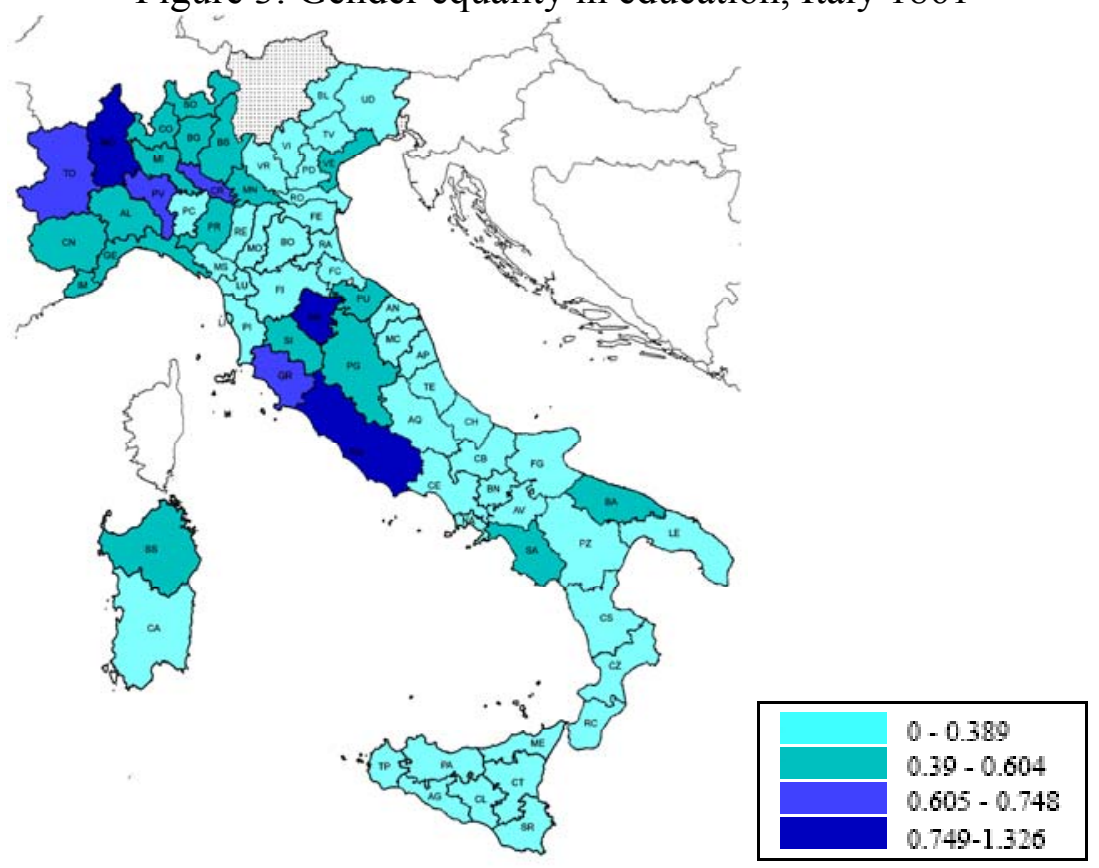

The darker the shade, the higher is the female to male ratio upper enrollment rate in the province. Provinces are identified by abbreviations of current provincial names. See the Appendix for sources.

Table 1 reports descriptive statistics for the upper-level female to male enrollment ratio in 1861, distinguishing between provinces that included a commercial center and provinces that did not. Medieval commercial hubs exhibit a higher mean score of about 0.44 against about 0.19 for the rest of the sample. This highly significant difference highlights the fact that provinces that hosted a commercial hub are associated with a more advantageous condition for women and put forth suggestive preliminary evidence of a relevant effect of the past legacy of trade on subsequent cultural norms regarding gender roles.

\footnotetext{
${ }^{24}$ The reason why enrollment rates can be greater than 100 percent is the presence of under-aged and/or over-aged enrollment. See the methodological notes in the Appendix for details.

${ }^{25}$ For some observations the ratio is larger than 1, which indicates a gender gap in favor of females.
} 
Table 1. Gender equality in education and medieval commerce, Italy 1861 , summary statistics

\begin{tabular}{lccc}
\hline \hline & \multicolumn{3}{c}{ Female to male ratio upper primary schooling rate } \\
\cline { 2 - 4 } & Whole sample & $\begin{array}{c}\text { Medieval } \\
\text { commercial hubs }\end{array}$ & Others \\
\cline { 2 - 4 } Observations & 69 & 36 & 33 \\
Mean & 0.316 & 0.435 & 0.186 \\
Std. Dev. & 0.290 & 0.315 & 0.191 \\
Min & 0 & 0 & 0 \\
Max & 1.326 & 1.326 & 0.652 \\
Difference & & \multicolumn{2}{c}{$-.250^{* * *}$} \\
\hline \hline
\end{tabular}

T-test is the two-sample mean comparison test $(\mathrm{Ha}=\mathrm{diff} \neq 0) . *, * *$, and $* * *$ denote significance at $10 \%, 5 \%$, and $1 \%$ levels.

\section{Regression results}

To assess the determinants of education inequalities across gender at the upper primary school level in Italy immediately following the Unification, we start in Table 2 with a bivariate OLS regression on our focal variable, medieval commerce (Column 1). The dependent variable is our main measure of gender equality in education, i.e., the female to male ratio in enrollment rates at the upper primary level. To be recalled is that our dependent variable should be interpreted as an index of gender equality in education, so that a positive coefficient indicates that the corresponding regressor is associated with more gender equality and thus a smaller gender gap. The coefficient of medieval commerce is significantly positive at the 1 percent level, indicating that provinces that were more closely involved with trade in the period running from the thirteenth to the fourteenth centuries exhibit a more favorable position for women in terms of education. The size of the coefficient suggests that provinces involved in trade are associated with a 25 percent higher ratio of the enrollment rates.

In Column 2 we add a set of standard geographical controls including latitude, longitude, access to sea, access to navigable river, and the prevalence of plain surface in the provincial territory, to capture the potential impact of factor endowments which may shape educational attainment in a gendered manner, for instance through agricultural techniques. The regression shows a substantial improvement of the R-squared and confirms the powerful influence of commerce. We keep including the geographical controls in all the subsequent specifications. 
Table 2. The determinants of gender equality in education, Italy 1861: OLS

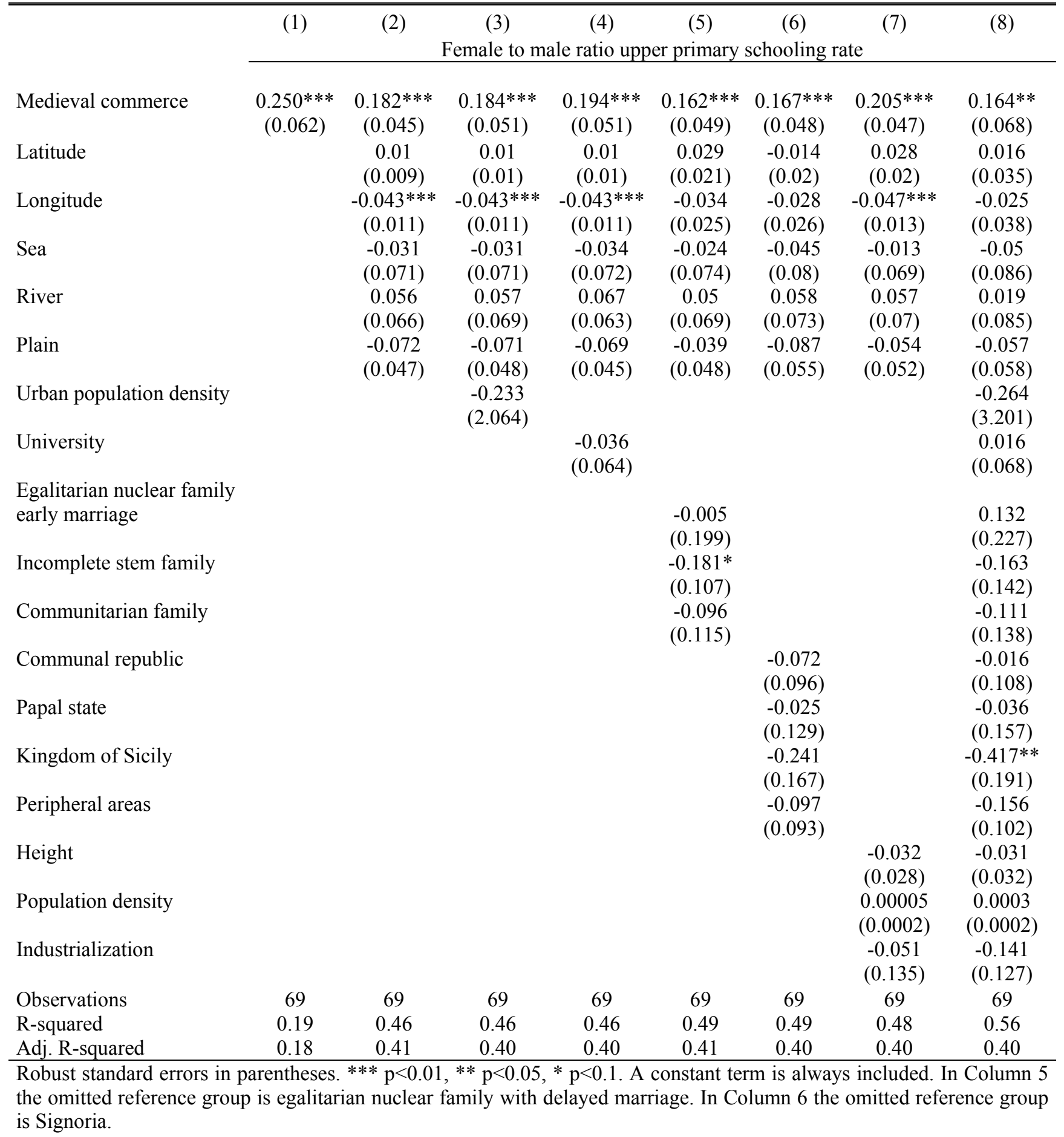

These preliminary cross sectional results document the existence of a previously unexplored strong correlation between medieval commerce in the late Middle Ages and our measure of gender equality in education in 1861 . However this correlation cannot be interpreted causally because of a number of concerns, primarily due to the potential presence of other observable and potentially confounding characteristics that may introduce a bias in the effect of medieval commerce. To respond to these concerns we control for a set of relevant variables broad enough to alleviate the omitted variables problem. In other words, our identification strategy takes care of the fact that the 
provinces affected by medieval commerce may differ from those that were not in other dimensions so that, at least after controlling for these other dimensions, "treated" and "untreated" provinces become comparable. By controlling for an extensive set of covariates, as we do in the rest of Table 2 , our goal is to capture any potential influence on the gender gap other than that of medieval commerce. The purpose of this exercise is not meant to deny the important role of additional factors, but simply to demonstrate that the influence of medieval commerce remains strong even accounting for them. We start by adding additional sets of controls one by one, but in the end we also enter them simultaneously.

The literature on gender roles points at several main potential determinants of gender equality. One could argue that the level of prosperity, which we capture with urban population density in medieval times, may have a persistent effect of subsequent gender equality, since more developed economies assign a greater role to the education and the social status of women. Moreover, the status of women in urban centers differed from that in rural areas. Furthermore, urban population density in the period under examination tends to be correlated with trade (even though in our sample the correlation is only 36 percent). Column 3 of Table 2 shows that the impact of medieval commerce is preserved after controlling for this potentially confounding factor, whose coefficient is not significant. ${ }^{26}$

The presence of an ancient university may also represent a force pushing for a cultural climate more favorable toward women's education and for the development of occupational opportunities more conducive to an active role of women. Nevertheless, the inclusion of this control (whose coefficient is insignificant) has little impact on our focal variable (Column 4).

It has also been argued that societies with patriarchal families are associated with an inferior status of women in all realms including education. After controlling for a rich set of dummies reflecting multiple aspects of family structure (namely, residential habits, inheritance rules, and age at marriage, along the classification we adapt from Todd, 1990 and Del Panta et al., 1996), again we find very similar estimates of the impact of medieval commerce (Column 5).

The political regimes prevailing in the Middle Ages may have implemented differentiated educational policies with a persistent influence along the gender dimension. Therefore, we also control for the fourteenth-century political regimes (i.e., Signorie, Communal republics, Papal State, Kingdom of Sicily, and peripheral areas) in Column 6. Once again the estimates for medieval commerce remain robust.

\footnotetext{
${ }^{26}$ As alternative proxies for income and prosperity Acemoglu et al. (2002) employ population density (defined as the ratio of population over surface) and urbanization (defined as the ratio of urban population over total population), while Cantoni (2015) relies on city size (measured by population). Since we do not have population data in 1300, we cannot measure population density and urbanization, but city size coincides with the numerator of our variable and is highly correlated with it (at the 0.76 percent level). If we substitute our variable with city size regressions results are similar (see Table A3, Column 1 in the Appendix).
} 
In a further set of regressions we control for other 1861 society's characteristics, i.e., the 1861 levels of height, population density, and industrialization, ${ }^{27}$ as proxies of prosperity and economic development, but they are never significant (Column 7). ${ }^{28}$ Contemporary levels of development may affect the gender gap in education for two reasons. First, the level of development is likely to affect the opportunity cost of education for girls, with larger gains from education in more industrialized provinces characterized by higher demand for skilled labor. Second, the supply side can also be involved since poor and rural provinces might be able to provide a lower number of female schools. However, since contemporaneous variables are likely to be endogenous we need to interpret these results with care, as they can potentially bias downward the estimate of our focal coefficient, which could therefore be interpreted as a lower bound.

Figure 4. Gender equality in education and medieval commerce

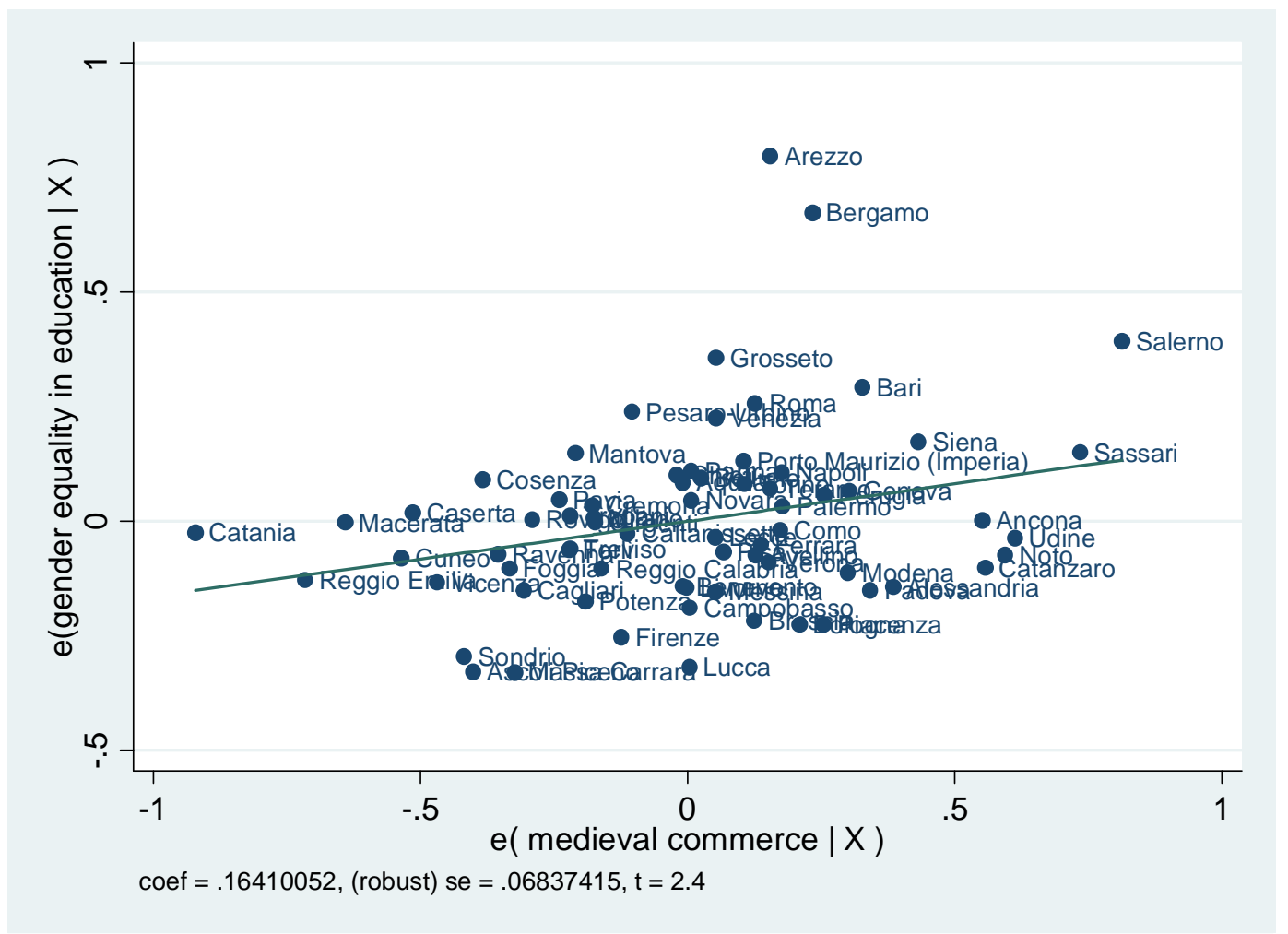

Finally, in Column 8 we enter together all the previous controls. Medieval commerce remains highly significant and associated with a 16.4 percent higher enrollment rate. In other words, the partial R-squared associated with medieval commerce suggests that it explains about 7.6 percent of the variation in residual female to male enrolment ratio in upper primary schools, conditional on our controls. Figure 4 reports the partial correlation plot for medieval commerce and our measure of gender equality in education in 1861 conditional on the controls included in the last specification

\footnotetext{
${ }^{27}$ The industrialization variable is from Ciccarelli and Fenoaltea (2013). See the Appendix for further details.

${ }^{28}$ Very similar results obtain if height is replaced by estimates of per capita value added due to Istituto Guglielmo Tagliacarne (2011) (see Table A3, Column 2 in the Appendix).
} 
(Column 8). We shall refer to this extended specification as a benchmark for the remaining of our analysis (even though, for brevity, we omit the coefficients of the additional covariates from the tables).

To further expand our analysis of the determinants of gender equality in education beyond the demand side, we now turn to the role of supply factors by introducing proxies for the supply of schooling and school quality. In Table 3 we add one by one to the regression the upper primary schooling rate, the overall primary schooling rate, the number of children (of age 6-10) per school, the number of children per teacher, and the number of pupils per teacher. All variables are measured in 1862-63 with the exception of the school variable involving the number of schools (where the number of children refers to 1870 and the number of schools to 1869). ${ }^{29}$ Only the coefficient of the upper primary schooling rate is significant, but results regarding the influence of medieval commerce are unaffected. In Column 6 of Table 3 we add the fraction of female teachers in primary public schools in 1861 (Vigo, 1971), which exhibits a positive coefficient, suggesting that the presence of female teachers may improve girls' opportunities. Since these additional variables are likely to be endogenous and they do not modify the conclusions regarding medieval commerce, we omit them from the following specifications.

Table 3. The determinants of gender equality in education: additional schooling measures, Italy 1861: OLS

\begin{tabular}{|c|c|c|c|c|c|c|}
\hline & (1) & (2) & (3) & (4) & (5) & (6) \\
\hline & \multicolumn{6}{|c|}{ Female to male ratio upper primary schooling rate } \\
\hline Medieval commerce & $\begin{array}{c}0.163^{* *} \\
(0.069)\end{array}$ & $\begin{array}{c}0.162 * * \\
(0.069)\end{array}$ & $\begin{array}{c}0.171^{* *} \\
(0.069)\end{array}$ & $\begin{array}{c}0.163^{* *} \\
(0.066)\end{array}$ & $\begin{array}{c}0.161^{* *} \\
(0.071)\end{array}$ & $\begin{array}{c}0.136^{* *} \\
(0.058)\end{array}$ \\
\hline Upper primary schooling rate & $\begin{array}{c}0.043 * * * \\
(0.013)\end{array}$ & & & & & \\
\hline Overall primary schooling rate & & $\begin{array}{c}0.003 \\
(0.003)\end{array}$ & & & & \\
\hline Number of children per school & & & $\begin{array}{c}-0.001 \\
(0.001)\end{array}$ & & & \\
\hline Number of children per teacher & & & & $\begin{array}{c}-0.001 \\
(0.001)\end{array}$ & & \\
\hline Number of pupils per teacher & & & & & $\begin{array}{c}0.003 \\
(0.005)\end{array}$ & \\
\hline Female teachers over total teachers & & & & & & $\begin{array}{c}0.012 * * \\
(0.005)\end{array}$ \\
\hline Observations & 69 & 69 & 69 & 69 & 69 & 69 \\
\hline R-squared & 0.63 & 0.57 & 0.56 & 0.56 & 0.56 & 0.64 \\
\hline Adj. R-squared & 0.48 & 0.40 & 0.39 & 0.39 & 0.39 & 0.49 \\
\hline
\end{tabular}

To further control for omitted variables we also pursue an instrumentation strategy based on the introduction of an external source of variation in the explanatory variable, medieval commerce, which we argue to be exogenous with respect to the dependent variable. Thus we run 2SLS regressions where medieval commerce is instrumented with the presence of a town in Italy in year

${ }^{29}$ See Section 4 and the Appendix for data definitions and sources. 
1000. The corresponding dummy is coded building on Bairoch et al. (1988) (see Section 4 and the Appendix). The choice of this instrument can be defended as follows.

At the turn of the first millennium, Europe had become a backward region of the world economy with low levels of urbanization and income (Davis, 1955; Pirenne, 1969; Cipolla, 1974; Bosker et al., 2008). In particular in Italy, despite the fact that the previous Greek and Roman eras had witnessed the flourishing of many prosperous centers, the fall of the Roman Empire provoked the disintegration of the previous equilibrium. The demise was due to largely exogenous events such as the barbarian invasions and the decline of Mediterranean trade as a consequence of Arab conquest in the seventh century. By year 1000 the closing of the Mediterranean and the raids from the North had determined a collapse of economic development and social order. Most of Europe had transformed into a rural, depopulated area, with few surviving towns. While in Northern Europe urban centers nearly disappeared, several Italian towns continued to exist despite their decline into isolated, agriculture-oriented and almost self-sufficient units. The factors that allowed the survival of a town by year 1000 are still debated among historians and can be attributed to the presence of an administrative center. Later on, during the course of the eleventh century, a new urban system emerged, as a consequence of technological progress in agriculture, improvements in the organization of commercial exchange, the promotion of new trade routes, and sustained population growth. This urban revolution originated from the towns that had previously survived, and laid the basis for the subsequent commercial revolution.

Therefore, our reading of the relevant historical literature suggests that the survival of a town in year 1000 is to be considered a precondition and a predictor of the subsequent development of commercial trade in the late Middle Ages. Indeed the correlation between the instrument and medieval commerce is 0.46 and highly significant, which suggests that our instrument is relevant. ${ }^{30}$

On the other hand, the exclusion restriction can be defended on the following grounds. Even if we cannot assume that the survival of a town in year 1000 was fully random, we can plausibly argue that such an historical event is an exogenous source of variation because determined by external factors. The economic and social order that had predated year 1000 was determined by the regional development patterns of the Greco-Roman world and thus was largely uncorrelated with the subsequent long-term resurgence of economic activity. Surviving towns merely reflected the tail of a previous world order and relied on agriculture rather than trade. In other words, even though the existence of a town in 1000 gave an initial advantage to commercial centers, the pre-1000 trade network was profoundly different from the trade network emerged after 1100 , so that the only influence of the presence of a town in 1000 would be via the initial impetus it gave to medieval commerce. ${ }^{31}$ Examples abound of surviving centers in 1000 that show no superior economic performance later on. ${ }^{32}$ Furthermore, it is also fair to argue that the probability of being a town in

\footnotetext{
${ }^{30}$ The pairwise correlation between the instrument and the female to male ratio upper primary schooling rate is 0.30 and significant at the 5 percent level.

${ }^{31}$ Indeed Bosker et al. (2008) report that around year 1000 the largest Italian cities were located in the South of the peninsula and in Sicily.

${ }^{32}$ For instance, if we take height as a proxy of economic activity, we find that both Bari and Salerno, which were towns in 1000 as well as trade centers later on, perform below average in 1861. Taking industrialization as an alternative
} 
year 1000 is not correlated with the degree of gender equality in education either in 1000 or in 1861.

Results are presented in Table 4, which shows that the coefficient for the instrument is highly significant in the first stage. The weak identification test yields an F-statistic well above the standard threshold value of 10 . The Hausman endogeneity test rejects the null so that, even if its validity hinges on the exclusion restriction, the 2SLS estimates are to be preferred over the OLS.

The coefficient of medieval commerce remains significant at the 1 percent level, confirming previous OLS results. However, the size of the IV estimate is now substantially higher than the corresponding OLS estimates. This difference in the estimated OLS and 2SLS coefficients might be the result of an attenuation bias of the OLS estimate due to measurement errors. However we acknowledge that the difference is too large to be explicable by measurement error alone and therefore these results should be taken with caution, since they may point to instrument invalidity, especially since we rely on a limited number of observations.

A further concern with our instrumentation strategy is that the characteristics of a town in year 1000 and therefore their survival might in turn be correlated with geographical features of the provinces. Moreover, richer or more developed provinces in the late Middle Ages might have influenced gender equality both in medieval times and in 1861. For this reasons, our specification exhaustively controls for the additional characteristics of the provinces included in the OLS benchmark estimates (among which geographical variables such as latitude, longitude, location on the sea and on a navigable river, as well as urban population density as a measure of prosperity in the late Middle Ages). Accordingly, we can argue that our instrument is plausible, conditional on our extensive set of controls.

We can therefore conclude that, at Unification, after controlling for a comprehensive set of longterm determinants reflecting geographic, economic, cultural, and political differences, gender inequality in education is significantly influenced by medieval commerce. As a result, the evidence so far collected, based on the available historical data, suggests that medieval commerce is a promising candidate explanation for the outcome at hand.

proxy, Ferrara and again Bari are examples of surviving towns and medieval trade centers with below average industrialization in 1871. In terms of population density (our third proxy for economic activity) Rome and Ferrara are examples of towns in 1000 and medieval trade centers with below average population density at Unification. 
Table 4. The determinants of gender equality in education, Italy 1861: 2SLS

(1)

Medieval commerce
(2)

Female to male ratio upper primary schooling

rate
Town 1000

Medieval commerce

Observations

R-squared

Weak Identification Test

Endogeneity p-value
$0.457 * * *$

(0.1)

69

0.62
$0.678 * * *$

$(0.243)$

69

0.20

15.10

0.03

Robust standard errors in parentheses. $* * * \mathrm{p}<0.01, * * \mathrm{p}<0.05, * \mathrm{p}<0.1$. Additional controls include: a constant, latitude, longitude, sea, river, plain, urban population density, university, dummies for family structure, dummies for political regimes, height, population density, and industrialization.

\section{Robustness checks and extensions}

To further check the robustness of our results, we run several other variants of the benchmark regressions in Table 2, Column 8, by applying alternative estimation methods, by including additional controls, by modifying the dependent variable, and by restricting our sample. Regressions results are reported in the Appendix (Table A3).

First we explore two alternative sets of clusters: at the level of the 12 districts ("circoscrizioni") defined by the 1884 Inchiesta Jacini (Column 3) and at the level of pre-unitary states (Column 4). In the first case, the significance level remains at 5 percent, while in the second case the significance of medieval commerce is actually higher, which points to within-cluster negative correlation. To control for potential spatial correlation patterns across provinces, we also run spatial error model regressions: the role of medieval commerce is confirmed (Column 5) and there is no statistical evidence of spatial autocorrelation in our main specification.

To the extent that there might be unobserved macro-regional heterogeneity, we include in the regression dummies reflecting four macro-regions (North West, North East, Center, and South) or, alternatively, the 12 Jacini districts (Column 6 and 7, respectively). We also replace our dummies for medieval political regimes with dummies reflecting the pre-Unification main ruling dynasties, i.e., Savoys, Habsburgs, Pope, and Bourbons, with the 1815-1861 period as a reference, in order to control for the possible long-lasting effects of policies enacted by more recent political dominations (Column 8).

We also modify the dependent variable, first by using simply the non weighted ratio of female to male enrollments rather than the corresponding rates, with and without a further control reflecting the ratio of female over male population of age 6-12, i.e., an (inverted) index of masculinity (Column 9 and 10, respectively). Next, in Column 11 we enter as dependent variable the percentage of females enrolled in upper primary schools, for direct comparison with Becker and Wößmann 
(2008). After controlling again for the (inverted) masculinity index, the coefficient of medieval commerce is still significant at the 10 percent level. These alternative functional forms for the dependent variable confirm a robust effect of medieval commerce on gender equality in education. ${ }^{33}$

Next we ensure that our estimates are not driven by measurement error by estimating the same regression over a sub-sample excluding the provinces located in Veneto and Mantua, which initially were still part of the Austrian territories, as well as Rome (Column 12). Data for these provinces are in fact taken from adjacent years (see the Appendix for further details). To make sure that the effect of medieval commerce is not driven by Turin, Florence, and Rome (i.e., the cities that alternated as capitals between 1861 and 1871) we run a specification without the corresponding three provinces (Column 13). We also restrict our sample in order to alleviate the risk of outliers, i.e., Bergamo and Arezzo (Column 14), whose removal does not affect our findings.

Overall, the same beneficial role of medieval commerce for women's education is always confirmed, with a significance level of at least 5 percent. In the remainder of this section we shall focus on additional extensions of the benchmark.

\subsection{Gender equality at the lower primary level and compulsory schooling}

When we regress on the same variables a measure of gender equality at the lower primary level, we find that medieval commerce exerts a positive but no longer significant effect, which suggests that the legacy of the distant past is not influential at the compulsory level (Table 5, Column 1) despite the fact that compliance was not full even at this level. However, the coefficient of medieval commerce is significant at the 10 percent level in less complete specifications, even though its size always remains lower if compared to the upper level. Thus, even at the legally compulsory level, there is still evidence of persistence of cultural beliefs on gender roles, despite the implementation of identical policies.

Indeed A'Hearn et al. (2011) explain how, despite the introduction of de jure compulsory schooling at the upper primary level in 1859, the law was applied only slowly and unevenly across the country. An influential factor was the degree of economic development, lower in parts of Southern Italy but also of Central Italy, but even in the relatively prosperous rural North mandatory schooling was disregarded since children were often employed in agriculture and in the textile industry. Moreover, ideological and political factors also played a role, with an aversion toward universal education on the part of some local elites. Buonazia (1873) reports the relevance both of supply factors, because of the insufficient provision of local funding, and of demand factors, since households were often reluctant to comply with the law. Giffoni and Gomellini (2015) analyze the determinants of the school attendance rate in Italy in the 1904-1911 period, which immediately

\footnotetext{
${ }^{33}$ Our results can be compared with those in Nunn (2014), who finds that the positive impact of African Protestant missions on women's education is not associated with a similar impact for men.
} 
follows our sample period. They show that across a sample of 85 cities the mean rate was still only 81.4 percent even after the promulgation of the Orlando Law in 1904 (see Section 3).

Similar results are obtained when, in place of gender equality at the lower primary level, we use gender equality in literacy as the dependent variable (Table 5, Column 2). Literacy rates are calculated as the share of individuals aged 5 or older who are able to read and write, measured in $1861 .^{34}$ Again gender equality is measured as the female to male ratio (on a 0-1 range) of literacy rates. ${ }^{35}$ Even though the correlation between the new variable and medieval commerce is 0.38 and significant, and the coefficient of medieval commerce would be significantly positive in less complete specifications, it is no longer significant in the complete specification shown. This is not surprising since literacy is much more strongly related to lower - rather than upper - primary school attendance.

Table 5. The determinants of gender equality in education, Italy 1861: lower primary level and literacy

\begin{tabular}{lcc} 
& $\begin{array}{c}\text { Female to male } \\
\text { ratio lower primary } \\
\text { schooling rate }\end{array}$ & $\begin{array}{c}\text { Female to male ratio } \\
\text { literacy rate }\end{array}$ \\
\cline { 2 - 3 } $\begin{array}{l}\text { Medieval } \\
\text { commerce }\end{array}$ & 0.043 & 0.028 \\
Observations & $(0.057)$ & -0.033 \\
R-squared & 69 & 69 \\
Adj. R-squared & 0.62 & 0.79 \\
\hline Robust standard errors in parentheses. ${ }^{* * *} \mathrm{p}<0.01,{ }^{* *} \mathrm{p}<0.05, *$ \\
$\mathrm{p}<0.1$. Additional controls include: a constant, latitude, longitude, \\
sea, river, plain, urban population density, university, dummies \\
for family structure, dummies for political regimes, height, \\
population density, and industrialization.
\end{tabular}

\subsection{The dynamics of gender equality in education}

As previously mentioned, our dataset reveals that the first decades after Unification witness a process of convergence across provinces in terms of gender equality in education. To investigate whether the legacy of medieval commerce has persisted within the convergence process, we perform a number of further checks. First, in Table 6 we present regressions for each of the available years in the sample, i.e., 1861,1881 , and $1901 .^{36}$ In 1881 the coefficient of medieval commerce remains significant, but only at the 10 percent level, while its size is more than halved. No residual effect remains in 1901. This confirms substantial but slow convergence in education outcomes across Italian provinces after Unification.

\footnotetext{
${ }^{34}$ For the provinces belonging to today's Veneto and for Mantua initial data refer to 1867, for Rome to 1872: this is due to the fact that the former territories were annexed to the new-born kingdom only in 1866, the latter in 1871.

${ }^{35}$ Data are taken from census, where the ability to read and write is reported through the answers to the following question asked to the household head: "How many people in your family are able to read or read and write?".

${ }^{36}$ Column 1 of Table 6 is identical to Column 8 of Table 2 but we still include it for ease of comparison.
} 
Table 6. The determinants of gender equality in education, Italy 1861, 1881, and 1901

\section{(1)}

Female to male ratio upper primary schooling rate

\section{Medieval commerce}

Observations

R-squared

Adj. R-squared

\begin{tabular}{ccc}
1861 & 1881 & 1901 \\
\hline $0.164^{* *}$ & $0.079^{*}$ & 0.032 \\
$(0.068)$ & $(0.046)$ & $(0.04)$
\end{tabular}

$69 \quad 69 \quad 69$

$\begin{array}{lll}0.56 & 0.53 & 0.48\end{array}$

$0.40 \quad 0.36 \quad 0.29$

Robust standard errors in parentheses. ${ }^{* * *} \mathrm{p}<0.01,{ }^{*} \mathrm{p}<0.05,{ }^{*} \mathrm{p}<0.1$. Additional controls include: a constant, latitude, longitude, sea, river, plain, urban population density, university, dummies for family structure, dummies for political regimes, height, population density, and industrialization.

In Table 7 we start by presenting a pooled specification spanning the entire period under examination (Column 1). Together with previous controls, we now include fixed time effects using year dummies. We also include dummies for four macro-regions (i.e., North West, North East, and South, with Center as the omitted one), which can be interpreted as broadly-defined spatial fixed effects. The influence of medieval commerce is confirmed. Next we add a set of interactions between medieval commerce and the time dummies (Column 2). Both interactions display negative coefficients even though only the second, involving year 1901, is significant. These findings confirm those obtained in Table 6, i.e., the influence of medieval commerce is declining, but only gradually, during the period under consideration. Finally in Column 3 we apply an even more flexible approach to allow the effect of medieval commerce to vary over time: medieval commerce enters only through interaction terms with the time dummies (where the interaction with 1861 is omitted). At the same time, we include province-level fixed effects, which allow to avoid all the potentially unobserved time-invariant province-level heterogeneity. ${ }^{37}$ This specification does not include all the other time-invariant variables. The declining role of medieval commerce in the convergence process is confirmed.

\footnotetext{
${ }^{37}$ See Cantoni (2015) for a similar approach to analysis of the time-varying influence of Protestantism on city size in early modern Germany.
} 
Table 7. The evolution of gender equality in education, Italy 1861-1901

\begin{tabular}{|c|c|c|c|}
\hline & (1) & (2) & (3) \\
\hline & \multicolumn{3}{|c|}{ Female to male ratio upper primary schooling rate } \\
\hline Medieval commerce & $\begin{array}{c}0.097 * * * \\
(0.03)\end{array}$ & $\begin{array}{c}0.162^{* * *} \\
(0.05)\end{array}$ & \\
\hline Year 1881 & $\begin{array}{c}0.312 * * * \\
(0.039)\end{array}$ & $\begin{array}{c}0.349 * * * \\
(0.043)\end{array}$ & $\begin{array}{c}0.369 * * * \\
(0.033)\end{array}$ \\
\hline Year 1901 & $\begin{array}{c}0.379 * * * \\
(0.044)\end{array}$ & $\begin{array}{c}0.445^{* * *} \\
(0.048)\end{array}$ & $\begin{array}{c}0.470 * * * \\
(0.031)\end{array}$ \\
\hline Medieval commerce * 1881 & & $\begin{array}{c}-0.07 \\
(0.056)\end{array}$ & $\begin{array}{c}-0.119 * * \\
(0.057)\end{array}$ \\
\hline Medieval commerce * 1901 & & $\begin{array}{c}-0.124 * * \\
(0.054)\end{array}$ & $\begin{array}{c}-0.177 * * * \\
(0.056)\end{array}$ \\
\hline Province FE & No & No & Yes \\
\hline Observations & 207 & 207 & 207 \\
\hline R-squared & 0.65 & 0.66 & 0.80 \\
\hline Adj. R-squared & 0.61 & 0.61 & 0.69 \\
\hline \multicolumn{4}{|c|}{$\begin{array}{l}\text { Robust standard errors in parentheses. } * * * \mathrm{p}<0.01, * * \mathrm{p}<0.05, * \mathrm{p}<0.1 \text {. In Columns } 1 \text { and } \\
\text { additional controls include: a constant, latitude, longitude, sea, river, plain, urban populatio } \\
\text { density, university, dummies for family structure, dummies for political regimes, heigh } \\
\text { population density, industrialization, and dummies for macro-regions. In Column } 3 \text { addition } \\
\text { controls include a constant and provincial fixed effects. }\end{array}$} \\
\hline
\end{tabular}

To sum up, the influence of medieval commerce is still very strong in 1861 at Unification, nearly six centuries after its development, and then declines but only slowly over our 40 -year sample. This pattern suggests that the new and countervailing forces that emerged after 1861, i.e., the political Unification of the country and the associated adoption and implementation of national educational policies aimed at the removal of disparities across regions and between genders, exerted an effect but only very gradually. As argued by Roland (2004), culture and beliefs can be viewed as slowmoving institutions, as opposed to fast-moving ones such as political institutions. Consistent with this view, our findings suggest that the new national educational policies were able to affect only slowly the previous equilibrium which had survived through cultural norms for centuries.

\subsection{Schooling}

Despite the fact that our results so far point at a powerful influence of medieval commerce on relative female education up to the beginning of the twentieth century, one may wonder whether medieval commerce might have had an influence not only on gender differences in education, but more generally on overall schooling. ${ }^{38}$. Results are presented in Table 8 . In Column 1 we enter as dependent variable the enrollment rate at the upper primary level. ${ }^{39} \mathrm{We}$ find that medieval commerce now displays a positive coefficient even though it is insignificant. Even in more parsimonious specifications the coefficient never becomes significant, suggesting that the influence it exerts on female versus male education has something to do with its peculiar gendered effect. In light of the similar beneficial effect - mentioned in the Introduction - of medieval commerce and Protestantism on women's education, our results are somewhat different from those in Becker and

\footnotetext{
${ }^{38}$ We refer to A'Hearn et al. (2011),Bertola and Sestito (2013), and Cappelli (2015) for a more general discussion on the determinants of schooling in Italy during the period under consideration.

${ }^{39}$ The rate is measured as the number of pupils enrolled in upper primary schools over the population of age 6-12.
} 
Wößmann (2008, 2009), who show that the positive impact of Protestantism on women's education was accompanied by a higher level of general education. This difference may be due to the fact that medieval commerce predates the diffusion of the Reform movement by several centuries, so that some of its influences may have dissipated earlier.

Table 8 . The determinants of schooling, Italy 1861

\begin{tabular}{lc}
\hline \hline & $\begin{array}{c}\text { Upper primary } \\
\text { schooling rate }\end{array}$ \\
\cline { 2 - 2 } Medieval commerce & 0.024 \\
& $(0.541)$ \\
Observations & 69 \\
R-squared & 0.61 \\
Adj. R-squared & 0.47 \\
\hline Robust standard errors in parentheses. $* * *$ p $<0.01, * * \mathrm{p}<0.05$, \\
$*$ p $<0.1$. Additional controls include: a constant, latitude, \\
longitude, sea, river, plain, urban population density, \\
university, dummies for family structure, dummies for political \\
regimes, height, population density, and industrialization.
\end{tabular}

\section{Evidence on cultural transmission}

While the evidence so far presented confirms a robust relationship between medieval commerce and the education of girls relative to boys, in terms of school attainment at Unification, in this section we extend the analysis to alternative indicators covering a broader time frame. In the search for support of our cultural persistence hypothesis, and in the absence of detailed data on gendered human capital accumulation during the centuries running between the expansion of trade and Italy's Unification, in the first sub-section we present additional pieces of evidence concerning the diffusion of abacus schools up to the Early Modern Era. Moreover, even though our main focus is on education, we explore the potential influence of medieval commerce on alternative outcomes reflecting contemporary family culture. Taken together, this additional suggestive evidence supports the hypothesis that the better education opportunities opened for girls in medieval commercial centers continuously affected cultural beliefs through centuries despite the change in the fundamentals that had originally driven their emergence.

\subsection{The diffusion of abacus schools up to the Renaissance}

We collect additional data on the presence of abacus schools in Italy during the Middle Ages and the subsequent Renaissance period. It should be stressed again that by the Renaissance the economic fundamentals that had originally justified the diffusion of abacus schools had been profoundly modified, with Italy no longer representing a strategic commercial hub. Nevertheless, historians have documented the persistence of this form of schooling up at least up to the sixteenth 
century and the Early Modern Era. The data, which are more detailed about the region of Tuscany but not limited to it, are presented in Table 9, which lists the towns for which the presence of an abacus school is documented on the basis of primary sources collected by Black (2007) and Ulivi (2008). As the table shows, we have information about the presence of abacus schools in 17 provinces. All of these provinces were associated with medieval commerce. In other words, there is no trace of abacus schools in any of the provinces not associated with medieval commerce. The correlation between medieval commerce and a dummy variable recording the presence of an abacus school in the corresponding province is equal to 0.55 percent. Since as discussed in Section 2 it is also documented that abacus schools were open to girls, this evidence confirms that up until the sixteenth century provinces that had been involved in medieval trade were still offering better opportunities to girls relative to other provinces, despite changes in the fundamentals that had made a difference two or three centuries earlier.

Table 9. Italian provinces hosting an abacus school

\begin{tabular}{|c|c|c|c|}
\hline \multicolumn{2}{|c|}{ Within Tuscany } & \multicolumn{2}{|c|}{ Outside Tuscany } \\
\hline Town & Province & Town & Province \\
\hline Florence & FI & Verona & VR \\
\hline Fusecchio & FI & Genoa & GE \\
\hline Pistoia & FI & Savona & GE \\
\hline Prato & FI & Bologna & $\mathrm{BO}$ \\
\hline Pisa & PI & Perugia & PG \\
\hline Volterra & PI & Città di Castello & PG \\
\hline Siena & SI & Palermo & PA \\
\hline San Geminiano & SI & Modena & MO \\
\hline Colle Valdelsa & SI & Brescia & BS \\
\hline Arezzo & $\mathrm{AR}$ & Milan & MI \\
\hline San Sepolcro & $\mathrm{AR}$ & Carmagnola & TO \\
\hline \multirow[t]{4}{*}{ Lucca } & LU & Chieri & TO \\
\hline & & Ferrara & FE \\
\hline & & Rome & RM \\
\hline & & Venice & VE \\
\hline
\end{tabular}

Table 9 also distinguishes between abacus schools within and outside Tuscany, since this was the region that witnessed the largest diffusion of abacus schools up to the sixteenth century. During the first half of the nineteenth century, i.e., about three centuries later, according to Vigo (1971) the Granduchy of Tuscany still had the highest proportion of female schools (47 percent) if compared to the other pre-unitary states. Again, after Unification (in 1863, 1881, and 1901) the proportion of female schools in Tuscany remains among the highest if compared to that of other regions.

Taken together, this evidence suggests that the legacy of medieval commerce, well past its historical apex, affects the availability of better education opportunities for girls throughout the centuries. A final consideration involves the distinction between cultural beliefs, as opposed to institutional persistence through education policies and the political system, as the driver of the transmission mechanisms at work. In fact, a case for the more prominent role of culture as opposed to institutions can be made as follows: prior to Unification, educational policies were not coordinated across the fast-changing and variegated political geography of the country. Moreover, abacus schools were not necessarily the outcome of public intervention, being promoted by private initiatives. Therefore, it is hard to conjecture that institutional persistence can drive our findings. Since economic 
fundamentals can also be ruled out as a driver, this reinforces the central thesis of transmission through cultural beliefs. ${ }^{40}$

\subsection{Gender and family culture}

A rich set of recent contributions has highlighted how the legacy of culture impacts on women's role in society in many dimensions and how cultural traits are transferred nearly unchanged from generation to generation (Bisin and Verdier, 2000; Guiso et al., 2006). The relevance of cultural factors in explaining female outcomes has been investigated by Guiso et al. (2006) and Fernandez and Fogli (2009). Similarly, Alesina and Giuliano (2010) stress the role of a specific trait of family culture, the strength of family ties, in shaping women's outcomes. Focusing on Italy, Campa et al. (2011) employ a measure of the gender gap in literacy in 1911 as an instrument for gender culture, which is in turn shown to affect the present gender gap in employment. Following the same intuition, Bozzano (2015) highlights that women's empowerment in politics and top managerial positions is highly correlated with past gender culture, as proxied by the gender gap in education in the late nineteenth century and the fertility rate in the early twentieth century, and that the transmission mechanism is through cultural values. These contributions suggest that cultural beliefs, rather than the persistence of economic incentives, represent a powerful channel of transmission.

To corroborate the above assumption for our focal variable, we explore the link between medieval commerce and family culture by collecting additional evidence on several indicators. We start with the cross-provincial diffusion of the egalitarian family type with late marriage, i.e., the family type which most closely reflects the predominant family structure in the present day and that, being characterized by nuclear residential habits, equal partition of inheritance, and late female marriage age, tends to be associated with a more equal status of women. As explained in Section 4, Todd (1990) documents the relevance of his family type classification up to the $1960 \mathrm{~s}$. We find a positive and significant correlation (equal to 0.18 ) between medieval commerce and the diffusion of this specific family type.

We also find a significant correlation between medieval commerce and other contemporary indicators of female emancipation selected by Bozzano (2015), namely family size in 1971 measured as the share of households with more than five members $(-0.26)$ and the share of religious marriages in $2004(-0.34) .^{41}$ A positive correlation is also found with the 2001 incidence of abortion (0.31), a measure of women's sexual liberation proposed by Braga and Checchi (2008). ${ }^{42}$

While this evidence is only suggestive, it further supports the hypothesis of cultural long-term persistence of the influence of the historical trade routes well past Italian Unification.

\footnotetext{
${ }^{40}$ For an alternative hypothesis based on changing fundamentals see instead Bleakley and Lin (2012) on the economic influence of portage sites in pre-nineteenth century North America.

${ }^{41}$ See Bozzano (2015) for variable definitions. The source for both variables is ISTAT (2011).

${ }^{42}$ The variable is defined as (number of abortions of women of age 20-24/ the female population of age 20-24) * 1.000. The source is ISTAT (2011).
} 


\section{Conclusion}

This work has explored the empirical determinants of the education gender gap and its evolution in historical perspective. Thus, it represents advancement within the literature about long-term persistence of deeply-rooted factors of economic and social development. Our investigation has been made possible through a newly-assembled dataset that covers a sample of Italian provinces in the 1861-1901 period, i.e., the initial forty years after the country's Unification.

In our search for the determinants of gender equality in education, after controlling for historical factors reflecting economic, geopolitical, and sociological covariates, we find robust evidence that its cross-sectional variation within Italian provinces at Unification is influenced by the medieval pattern of commerce, along the routes that connected Italian cities among themselves and with the rest of the world in the fourteenth century. The empirical link we uncover suggests that having a past as a medieval commercial hub might have created the favourable preconditions for the transformation of the mentality concerning the role of women in society, ending up in a more egalitarian set of cultural norms and beliefs transmitted through generations.

A parallel investigation of the determinants of schooling reveals that medieval commerce is no longer a significant determinant, which points to its peculiar influence not so much on overall human capital accumulation but rather on its gendered component. Exploring the convergence process that characterizes the post-Unification period, we find the medieval commerce has a declining but persistent influence over gender equality in education, which implies that it took decades before the schooling policies imposed at the national level at Unification were capable of diluting its century-long cultural influence. Moreover, evidence on a long-term influence of medieval commerce on contemporary outcomes emerges within the realm of gender and family culture.

Italy's Unification occurred over a century and a half ago: while the evidence we present refers to the initial forty years, gender equality in education is currently established at the compulsory schooling level, and even reversed for the younger cohorts at the college level. However, in the developing world, discrimination towards girls with respect to educational opportunities is still a key issue, to the point that gender equality in education is one of the eight Millennium Development Goals. In fact, as reported by the latest report (United Nations, 2015) we are now entering a crucial stage that witnesses, for a majority of developing countries, a dramatic decline of gender disparity at all levels of education: overall, many more girls are in school today compared to 15 years ago, with the achievement of gender parity in primary education in 64 percent of the countries covered. However, significant gaps persist at higher levels and regional disparities are persistent: the most substantial progress has been recorded in Southern Asia, while sub-Saharan Africa is still lagging behind. Poor education is systematically associated with deeply-rooted, unequal gender norms affecting the economic and political realms. These facts confirm the relevance of educating women and girls for policy makers around the world and suggest that programs and targets for contemporary actions should take history and culture into consideration. 


\section{References}

Acemoglu, D., Autor, D.H., Lyle, D., 2004. Women, War, and Wages: The Effect of Female Labor Supply on the Wage Structure at Midcentury. Journal of Political Economy 112, 497-551.

Acemoglu, D., Johnson, S., Robinson, J.A., 2002. Reversal of Fortune: Geography and Institutions in the Making of the Modern World Income Distribution. Quarterly Journal of Economics 117, 1231-1294.

A’Hearn, B., Auria, C., Vecchi, G., 2011. Istruzione. In Vecchi, G. (ed.), In Ricchezza e in Povertà: Il Benessere degli Italiani dall'Unità a Oggi. Ch. 5. Il Mulino, Bologna. 159-206.

A'Hearn, B., Peracchi, F., Vecchi, G., 2009. Height and the Normal Distribution: Evidence from Italian Military Data. Demography 46, 1-25.

Alesina, A.F., Giuliano, P., 2010. The Power of the Family. Journal of Economic Growth 15, 93-125.

Alesina, A.F., Giuliano, P., Nunn, N., 2013. On the Origins of Gender Roles: Women and the Plough. Quarterly Journal of Economics 128, 469-530.

Arruñada, B., 2010. Protestants and Catholics: Similar Work Ethic, Different Social Ethic. Economic Journal 120, 890-918.

Atlante Storico Treccani, 2007. Istituto della Enciclopedia Italiana, Rome.

Bairoch, P., Batou, J., Chevre, P., 1988. La Population des Villes Européennes de 800 à 1850. Librairie Droz, Geneva.

Becker, S.O., Wößmann, L., 2009. Was Weber Wrong? A Human Capital Theory of Protestant Economic History. Quarterly Journal of Economics 124, 531-596.

Becker, S.O., Wößmann, L., 2008. Luther and the Girls: Religious Denomination and the Female Education Gap in Nineteenth-century Prussia. Scandinavian Journal of Economics 110, 777-805.

Beltran Tapia, F.J., Martinez-Galarraga, J., 2015. Land Access Inequality and Education in Pre-industrial Spain. University of Oxford Discussion Paper No. 137.

Benavot, A., Riddle, P., 1988. The Expansion of Primary Education, 1870-1940: Trends and Issues. Sociology of Education 61, 191-210.

Bertocchi, G., 2011. The Enfranchisement of Women and the Welfare State. European Economic Review 55, 535-553.

Bertocchi. G., Bozzano, M., 2015. Family Structure and the Education Gender Gap: Evidence from Italian Provinces. CESifo Economic Studies 61, 263-300.

Bertocchi, G., Brunetti, M., Torricelli, C., 2014. Who Holds the Purse Strings within the Household? The Determinants of Intra-family Decision Making. Journal of Economic Behavior \& Organization 101, 65-86.

Bertocchi, G., Spagat, M., 1997. Il Ruolo dei Licei e delle Scuole Tecnico-Professionali tra Progresso Tecnologico, Conflitto Sociale e Sviluppo Economico. In Rossi, N. (ed.), L'Istruzione in Italia: Solo un Pezzo di Carta? Il Mulino, Bologna. 421-459.

Bertola, G., Sestito, P., 2013. Human Capital. In Toniolo, G. (ed.), The Oxford Handbook of the Italian Economy since Unification. Ch. 9. Oxford University Press, New York. 249-270.

Bisin, A., Verdier, T., 2000. Beyond the Melting Pot: Cultural Transmission, Marriage, and the Evolution of Ethnic and Religious Traits. Quarterly Journal of Economics 115, 955-88.

Black, R., 2007. Education and Society in Florentine Tuscany: Teachers, Pupils and Schools, c. 1250-1500. Brill, Leiden-Boston.

Bleakley, H., Lin, J., 2012. Portage and Path Dependence. Quarterly Journal of Economics 127, 587-644.

Boccaccio, G., 1972. The Decameron. McWilliam, G. H. (transl.). Penguin Books, London.

Boerner, L., Severgnini, B., 2012. Epidemic Trade. EHES Working Paper No. 24. 
Bøler, E.A., Javorcikz, B., Ulltveit-Moe, K.H., 2015. Globalization: A Woman's Best Friend? Exporters and the Gender Wage Gap. Mimeo.University of Oslo.

Boserup, E., 1970. Woman's Role in Economic Development. George Allen and Unwin Ltd., London.

Bosker, M., Brakman, S., Garretsen, H., Jong, H., Schramm, M., 2008. Ports, Plagues and Politics: Explaining Italian City Growth 1300-1861. European Review of Economic History 12, 97-131.

Bozzano, M., 2015. On the Historical Roots of Women's Empowerment across Italian Province: Religion or Family Culture? RECent Working Paper No. 110.

Bozzano, M., 2014. Assessing Gender Inequality among Italian Regions: The Italian Gender Gap Index. Rivista di Politica Economica 103, 255-300.

Braga, M., Checchi, D., 2008. Closing the Gender Gap? Life Competences and Social Environment. Rivista di Politica Economica 98, 155-198.

Braun, S., Kvasnicka, M., 2013. Men, Women, and the Ballot: Gender Imbalances and Suffrage Extensions in the United States. Explorations in Economic History 50, 405-426.

Buonazia, G., 1873. Documenti sull' Istruzione Elementare nel Regno d'Italia, Parte III. Botta, Rome.

Buonazia, G., 1870. Documenti sulla Istruzione Elementare del Regno d'Italia, Parte II. Eredi Botta, Florence.

Byrne, J., 1996. Crafting the Merchant's Wife's Tale: Historians and the Domestic Rhetoric in the Correspondence of Margherita Datini (1360-1425). Journals of the Georgia Association of Historians 17, 1-17.

Campa, P., Casarico, A., Profeta, P., 2011. Gender Culture and Gender Gap in Employment. CESifo Economic Studies 57, 156-182.

Cantoni, D., 2015. The Economic Effects of the Protestant Reformation: Testing the Weber Hypothesis in the German Lands. Journal of the European Economic Association 13, 561-598.

Cantoni, D., Yuchtman, N., 2014. Medieval Universities, Legal Institutions, and the Commercial Revolution. Quarterly Journal of Economics 129, 823-887.

Cappelli, G., 2015. One Size that Didn't Fit All? Electoral Franchise, Fiscal Capacity and the

Rise of Mass Schooling across Italy's Provinces, 1870 - 1911”. Cliometrica, forthcoming.

Ciccarelli, C., Fenoaltea, S., 2013. Through the Magnifying Glass: Provincial Aspects of Industrial Growth in Post-Unification Italy. Economic History Review 66, 57-85.

Cipolla, C.M., 1974. Storia Economica dell'Europa Pre-Industriale. Il Mulino, Bologna.

Cipolla, C.M., 1969. Literacy and Development in the West. Penguin Books, Harmondsworth.

Crabb, A., 2007. "If I Could Write": Margherita Datini and Letter Writing, 1385-1410. Renaissance Quarterly 60, 1170-1206.

Davis, K., 1955. The Origin and Growth of Urbanization in the World. American Journal of Sociology 60, 429-437.

De Blasio, G., Nuzzo, G., 2010. Historical Traditions of Civicness and Local Economic Development. Journal of Regional Science 50, 833-857.

Del Panta, L., Livi Bacci, M., Pinto, G., 1996. La Popolazione Italiana dal Medioevo a Oggi. Laterza, Rome.

De Mauro, T., 1963. Storia Linguistica dell'Italia Unita. Laterza, Bari.

Dincecco, M., Federico, G., Vindigni, A., 2011. Warfare, Taxation, and Political Change: Evidence from the Italian Risorgimento. Journal of Economic History 71, 887-914.

Diviccaro, A., 1999. Il Lavoro delle Donne in un Centro di Terra di Bari: Barletta tra XI e XV Secolo. Archivio Storico Pugliese 52, 75-112.

Doepke, M., Hazan, M., Maoz, Y.D., 2015. The Baby Boom and World War II: A Macroeconomic Analysis. Review of Economic Studies, forthcoming. 
Doepke, M., Tertilt, M. 2009. Women's Liberation: What's In It for Men? Quarterly Journal of Economics 124, 1541-1591.

Doni Garfagnini, M., 1999. Conduzione Familiare e Vita Cittadina nelle Lettere di Alessandra Macinghi Strozzi. In Zarri, G. (ed.), Per Lettera: La Scrittura Epistolare Femminile tra Archivio e Tipografia. Viella, Rome. 387-411.

Duby, C., Perrot, M., 1998. L'Histoire des Femmes en Occident. Flammarion, Paris.

Duranton, G., Rodriguez-Pose, A., Sandall, R., 2009. Family Types and the Persistence of Regional Disparities in Europe. Economic Geography 85, 23-47.

Fanfani, A., 1968. Storia Economica. Parte Prima. Antichità - Medioevo - Età Moderna. Unione Tipografico-editrice Torinese, Turin.

Fernandez, R., 2013. Cultural Change as Learning: The Evolution of Female Labor Force Participation over a Century. American Economic Review 103, 472-500.

Fernandez, R., Fogli, A., 2009. Culture: An Empirical Investigation of Beliefs, Work, and Fertility. American Economic Journal: Macroeconomics 1, 146-177.

Fernandez, R., Wong, J.C., 2011. The Disappearing Gender Gap: The Impact of Divorce, Wages, and Preferences on Education Choices and Women's Work. Mimeo, New York University.

Fogel, R.W., Engerman, S.L., Trussell, J., 1982. Exploring the Uses of Data on Height: The Analysis of Long-Term Trends in Nutrition, Labor Welfare, and Labor Productivity. Social Science History 6, 401-421.

Fogli, A., Veldkamp, L., 2011. Nature or Nurture? Learning and the Geography of Female Labor Force Participation. Econometrica 79, 1103-1138.

Galasso, V., Profeta, P., 2011. When the State Mirrors the Family: The Design of Pension Systems. CEPR Discussion Paper No. 8723.

Galor, O., Weil, D.N., 1996. The Gender Gap, Fertility, and Growth. American Economic Review 86, 274-387.

Gibbins, H. de B., 1891. The History of Commerce in Europe. Macmillan, London.

Giffoni, F., Gomellini, M., 2015. Brain Gain in the Age of Mass Migration. Banca d'Italia Quaderni di Storia Economica No. 34.

Goldin, C., 2006. The Quiet Revolution That Transformed Women's Employment, Education, and Family. American Economic Review Papers and Proceedings 96, 1-21.

Goldin, C., 1998. America's Graduation from High School: The Evolution and Spread of Secondary Schooling in the Twentieth Century. Journal of Economic History 58, 345-374.

Goldin, C., 1991. The Role of World War II in the Rise of Women's Employment. American Economic Review 81, 741-756.

Goldin, C., Katz, L.F., Kuziemko, I., 2006. The Homecoming of American College Women: The Reversal of the Gender Gap in College. Journal of Economic Perspectives 20, 133-156.

Goldin, C., Olivetti, C., 2013. Shocking Labor Supply: A Reassessment of the Role of World War II on U.S. Women's Labor Supply. American Economic Review Papers and Proceedings 103, 257-262.

Grendler, P.F., 1989. Schooling in Renaissance Italy: Literacy and Learning, 1300-1600. Johns Hopkins University Press, Baltimore.

Guiso, L., Sapienza, P., Zingales, L., 2006. Does Culture Affect Economic Outcomes? Journal of Economic Perspectives 20, 23-48.

Hausmann, R.D., Tyson, L., Zahidi, S., 2007. The Global Gender Gap Report. World Economic Forum, Geneva.

Hoftijzer, P., 2001. Metropolis of Print: The Amsterdam Book Trade in the Seventeenth Century. In O'Brien, P. (ed.), Urban Achievement in Early Modern Europe: Golden Ages in Antwerp, Amsterdam, and London. Cambridge University Press, New York. 
Incatasciato, B., 1978. Leggere, Scrivere, Far di Conto. Per una Storia della Didattica nella Scuola Elementare. In Tomasi, T., Genovesi, G., Tancredi Torelli, M.P., Incatasciato, B., Ulivieri, S., Catarsi, E. (eds.), L'Istruzione di Base in Italia (1859-1977). Vallecchi, Florence. 128-134.

ISTAT, 2011. Sistema di Indicatori Territoriali. http://sitis.istat.it/sitis/html/index.htm.

Istituto Guglielmo Tagliacarne, 2011. Reddito e Occupazione nelle Province Italiane dal 1861 ad Oggi. Istituto Guglielmo Tagliacarne, Rome.

Lagerlöf , N.-P., 2003. Gender Equality and Long-Run Growth. Journal of Economic Growth 8, 403-426.

Luzzatto, G., 1963. Storia Economica d'Italia. Il Medioevo. Biblioteca Sansoni, Florence.

MAIC, 1864. Popolazione: Censimento Generale (31 Dicembre 1861). Tipografia Letteraria, Turin.

MAIC, 1865. Statistica del Regno d'Italia. Istruzione Pubblica e Privata. Anno scolastico 186263. Enrico Dalmazzo Tipografo, Turin.

MAIC, 1868. Statistica del Regno d'Italia, Popolazione, Movimento dello Stato Civile del 1867. Tipografia Tofani, Florence.

MAIC, 1872. Censimento della Popolazione del Regno d'Italia al 31 dicembre 1871. Stamperia Reale, Rome.

MAIC, 1883. Censimento della Popolazione del Regno d'Italia al 31 dicembre 1881. Tipografia Bodoniana, Rome.

MAIC, 1884. Statistica della Istruzione Primaria e Normale per l'Anno Scolastico 1881-82. Tipografia Nazionale, Rome.

MAIC, 1902. Censimento della Popolazione del Regno d'Italia al 10 Febbraio 1901. Tipografia Nazionale Bertero, Rome.

MAIC, 1906. Statistica della Istruzione Primaria e Normale per l'Anno Scolastico 1901-02. Tipografia Nazionale Bertero, Rome.

Malanima, P., 1998. Italian Cities 1300-1861. A Quantitative Approach. Rivista di Storia Economica 14, 91-126.

Miglio, L., 2008. Governare l'Alfabeto. Donne, Scrittura e Libri nel Medioevo. Viella, Rome.

Nunn, N., 2014. Gender and Missionary Influence in Colonial Africa. In Akyeampong, E., Bates, R., Nunn, N., Robinson, J.A. (eds.), Africa's Development in Historical Perspective. Cambridge University Press. 489-512.

Ogilvie, S., 2014. The Economics of Guilds. Journal of Economic Perspectives 28, 169-192.

Palermo, M., 2010. Lettere e Epistolografia. In Enciclopedia dell'Italiano, Treccani.it.

Pécout, G., 1999. Il Lungo Risorgimento: La Nascita dell'Italia Contemporanea (1770-1922). Edizioni Bruno Mondadori, Milan.

Percoco, M., 2014. Path Dependence, Institutions, and the Density of Economic Activities: Evidence from Italian Cities. Papers in Regional Science 93, 53-76.

Perrin, F., 2014. On the Construction of a Historical Gender Gap Index. An Implementation on French Data. AFC Working Paper No. 5.

Piccinni, G., 1999. I Mille Anni del Medioevo. Bruno Mondadori, Milan.

Pirenne, H., 1969. Medieval Cities, their Origins and the Revival of Trade. Princeton University Press, Princeton.

Rashdall, H., 1987. The Universities of Europe in the Middle Ages. New Edition. Clarendon Press, Oxford.

Ricci, A., 2011. Mercanti e Lingua. In Enciclopedia dell'Italiano, Treccani.it.

Richardson, M., 1997. Women, Commerce, and Rhetoric in Medieval England. In Wertheimer, M. (ed.), Listening to their Voices: The Rhetorical Activities of Historical Women. University of South Carolina Press, Columbia. 
Roland, G., 2004. Understanding Institutional Change: Fast-Moving and Slow-Moving Institutions. Studies in Comparative International Development 38, 109-131.

Sacchi, G., 1858. Le Scuole Reali Inferiori ed Elementari nelle Provincie Venete. Annali Universali di Statistica, Economia Pubblica, Legislazione, Storia, Viaggi e Commercio No. 133.

Sapori, A., 1972. La Mercatura Medievale. Sansoni, Florence.

Schultz, T.P., 2002. Why Governments Should Invest More to Educate Girls. World

Development 30, 207-225.

Serristori, L., 1842. Statistica dell'Italia. Stamperia Granducale, Florence.

Shepherd, W.R., 1926. Historical Atlas. 5th Edition. Holt, New York.

Skinner, P., 2004. Donne nel Commercio Amalfitano (Secoli X-XII). In Casagrande, G. (ed.), Donne tra Medioevo ed Età Moderna in Italia: Ricerche. Morlacchi, Perugia. 1-22.

Spufford, M., 1995. Literacy, Trade and Religion in the Commercial Centres of Europe. In Davids, K., Licassen, J. (eds.), A Miracle Mirrored: The Dutch Republic in European Perspective. Cambridge University Press, Cambridge. 229-283.

Todd, E., 1990. L'Invention de l'Europe. Seuil, Paris.

Uitz, E., 1990. Legend of Good Women: Medieval Women in Towns and Cities. Moyer Bell, New York.

Ulivi, E., 2008. Scuole d'Abaco e Insegnamento della Matematica. In Fontana, G.L., Molà, L. (eds.), Il Rinascimento Italiano e l'Europa, vol. V. Angelo Colla, Costabissara. 403-420.

United Nations, 2015. Millennium Development Goals Report.United Nations, New York.

Vigo, G., 1971. Istruzione e Sviluppo Economico in Italia nel Secolo XIX, Archivio Economico dell'Unificazione Italiana, Serie II, vol. XVIII. ILTE, Turin.

Wiesner, M.E., 2000. Women and Gender in Early Modern Europe. Second Edition. Cambridge University Press, Cambridge.

Xue, M.M., 2015, Textiles and the Historical Emergence of Gender Equality in China. Mimeo, George Mason University.

Zamagni, V., 2002. L'Offerta di Istruzione in Italia 1861-1981: Un Fattore Guida dello Sviluppo o un Ostacolo? In Gilli, G., Lupo, M., Zilli, I. (eds.), Scuola e Società. Le Istituzioni Scolastiche in Italia dall'Età Moderna al Futuro. ESI, Naples. 143-182.

\section{APPENDIX}

This appendix describes the data underlying our study in more detail. The dataset contains information from 69 Italian provinces at 1871 boundaries. We collect province-level data for three points in time $(1861,1881,1901)$ spanning the first forty years after Italian Unification. Table A1 contains variable definitions and sources. Whenever needed, detailed methodological notes on the construction of the dataset follow next. Table A2 presents summary statistics.

Table A1. Variable definitions and sources

\begin{tabular}{|l|l|l|l|}
\hline \multicolumn{1}{|c|}{ Variable } & \multicolumn{1}{|c|}{ Definition } & \multicolumn{1}{c|}{ Construction } & \multicolumn{1}{c|}{ Main Source } \\
\hline Medieval commerce & & $\begin{array}{l}\text { Dummy variable: 1 if main town lies } \\
\text { on medieval commerce routes or was a } \\
\text { commercial hub, fair or bank seat in } \\
\text { late Middle Ages, 0 otherwise }\end{array}$ & $\begin{array}{l}\text { Fanfani (1968), Luzzatto } \\
\text { (1963), Piccinni (1999), } \\
(2007), \text { Shepherd (1926) }\end{array}$ \\
\hline Schooling rate & $\begin{array}{l}\text { Gross primary school } \\
\text { enrollment rate }\end{array}$ & $\begin{array}{l}\text { Pupils enrolled in primary } \\
\text { school/population of primary school } \\
\text { age (6-12) } * 100\end{array}$ & MAIC (various years) \\
\hline
\end{tabular}




\begin{tabular}{|c|c|c|c|}
\hline Lower schooling rate & $\begin{array}{l}\text { Gross lower primary school } \\
\text { enrollment rate }\end{array}$ & $\begin{array}{l}\text { Pupils enrolled in lower primary } \\
\text { school/ population of primary school } \\
\text { age }(6-12) * 100\end{array}$ & MAIC (various years) \\
\hline Upper schooling rate & $\begin{array}{l}\text { Gross upper primary school } \\
\text { enrollment rate }\end{array}$ & $\begin{array}{l}\text { Pupils enrolled in upper primary } \\
\text { school/ population of primary school } \\
\text { age }(6-12) * 100\end{array}$ & MAIC (various years) \\
\hline Male schooling rate & $\begin{array}{l}\text { Male gross primary school } \\
\text { enrollment rate }\end{array}$ & $\begin{array}{l}\text { Male pupils enrolled in primary school/ } \\
\text { male population of primary school age } \\
(6-12) * 100\end{array}$ & MAIC (various years) \\
\hline Female schooling rate & $\begin{array}{l}\text { Female gross primary } \\
\text { school enrollment rate }\end{array}$ & $\begin{array}{l}\text { Female pupils enrolled in primary } \\
\text { school/ female population of primary } \\
\text { school age }(6-12) * 100\end{array}$ & MAIC (various years) \\
\hline $\begin{array}{l}\text { Female to male ratio } \\
\text { schooling rate }\end{array}$ & $\begin{array}{l}\text { Female gross primary } \\
\text { school enrollment rate over } \\
\text { male gross primary school } \\
\text { enrollment rate (range } 0-1 \text { ) } \\
=\text { Gender Parity Index in } \\
\text { primary school }\end{array}$ & $\begin{array}{l}\text { [Female pupils enrolled in primary } \\
\text { school/ female population of primary } \\
\text { school age (6-12)]/ [male pupils } \\
\text { enrolled in primary school/ male } \\
\text { population of primary school age (6- } \\
\text { 12)] = female pupils enrolled in } \\
\text { primary school/ male pupils enrolled in } \\
\text { primary school * masculinity of } \\
\text { primary school age (6-12) population }\end{array}$ & MAIC (various years) \\
\hline $\begin{array}{l}\text { Female to male ratio } \\
\text { upper schooling rate }\end{array}$ & $\begin{array}{l}\text { Female gross upper } \\
\text { primary school enrollment } \\
\text { rate over male gross upper } \\
\text { primary school enrollment } \\
\text { rate (range } 0-1 \text { ) = Gender } \\
\text { Parity Index in upper } \\
\text { primary school }\end{array}$ & $\begin{array}{l}\text { Female pupils enrolled in upper } \\
\text { primary school/ male pupils enrolled in } \\
\text { upper primary school * masculinity of } \\
\text { primary school age (6-12) population }\end{array}$ & MAIC (various years) \\
\hline $\begin{array}{l}\text { Female to male ratio } \\
\text { lower schooling rate }\end{array}$ & $\begin{array}{l}\text { Female gross lower } \\
\text { primary school enrollment } \\
\text { rate over male gross lower } \\
\text { primary school enrollment } \\
\text { rate (range } 0-1)=\text { Gender } \\
\text { Parity Index in lower } \\
\text { primary school }\end{array}$ & $\begin{array}{l}\text { Female pupils enrolled in lower } \\
\text { primary school/ male pupils enrolled in } \\
\text { lower primary school * masculinity of } \\
\text { primary school age (6-12) population }\end{array}$ & MAIC (various years) \\
\hline Masculinity index & $\begin{array}{l}\text { Masculinity of primary } \\
\text { school age }(6-12) \\
\text { population }\end{array}$ & $\begin{array}{l}\text { Male population of primary school age } \\
\text { (6-12)/ female population of primary } \\
\text { school age (6-12) }\end{array}$ & Census (various years) \\
\hline Latitude & & $\begin{array}{l}\text { Latitude of the main city of the } \\
\text { province in decimal degrees }\end{array}$ & Passim \\
\hline Longitude & & $\begin{array}{l}\text { Longitude of the main city of the } \\
\text { province in decimal degrees. }\end{array}$ & Passim \\
\hline Sea & & $\begin{array}{l}\text { Dummy variable: } 1 \text { if the province is } \\
\text { located on a sea, } 0 \text { otherwise }\end{array}$ & $\begin{array}{l}\text { Atlante Storico Treccani } \\
(2007)\end{array}$ \\
\hline River & & $\begin{array}{l}\text { Dummy variable: } 1 \text { if the province is } \\
\text { located on a navigable river, } 0 \\
\text { otherwise }\end{array}$ & $\begin{array}{l}\text { Atlante Storico Treccani } \\
(2007)\end{array}$ \\
\hline Plain & & $\begin{array}{l}\text { Categorical variable: } 2 \text { if provincial } \\
\text { surface is prevalently plain, } 1 \text { if hilly, } 0 \\
\text { if mountaineous }\end{array}$ & Passim \\
\hline $\begin{array}{l}\text { Urban population } \\
\text { density }\end{array}$ & & $\begin{array}{l}\text { Total population (in thousands) of all } \\
\text { cities belonging to a province (at } 1871 \\
\text { boundaries) in 1300/provincial surface } \\
\text { in squared kilometers }\end{array}$ & Malanima (1998) \\
\hline University & & $\begin{array}{l}\text { Dummy variable: } 1 \text { if the main town of } \\
\text { the province is the seat of ancient } \\
\text { university or studium, } 0 \text { otherwise }\end{array}$ & Passim \\
\hline $\begin{array}{l}\text { Egalitarian nuclear } \\
\text { family with early }\end{array}$ & & $\begin{array}{l}\text { Dummy variable: } 1 \text { if the egalitarian } \\
\text { nuclear family type with early marriage }\end{array}$ & $\begin{array}{l}\text { Todd (1990), Del Panta et } \\
\text { al. (1996) }\end{array}$ \\
\hline
\end{tabular}




\begin{tabular}{|c|c|c|c|}
\hline marriage & & $\begin{array}{l}\text { prevailed in the Middle Ages, } 0 \\
\text { otherwise }\end{array}$ & \\
\hline $\begin{array}{l}\text { Egalitarian nuclear } \\
\text { family with delayed } \\
\text { marriage }\end{array}$ & & $\begin{array}{l}\text { Dummy variable: } 1 \text { if the egalitarian } \\
\text { nuclear family type with late marriage } \\
\text { prevailed in the Middle Ages, } 0 \\
\text { otherwise }\end{array}$ & $\begin{array}{l}\text { Todd (1990), Del Panta et } \\
\text { al. (1996) }\end{array}$ \\
\hline $\begin{array}{l}\text { Incomplete stem } \\
\text { family }\end{array}$ & & $\begin{array}{l}\text { Dummy variable: } 1 \text { if the incomplete } \\
\text { stem family type prevailed in the } \\
\text { Middle Ages, } 0 \text { otherwise }\end{array}$ & $\begin{array}{l}\text { Todd (1990), Del Panta et } \\
\text { al. (1996) }\end{array}$ \\
\hline $\begin{array}{l}\text { Communitarian } \\
\text { family }\end{array}$ & & $\begin{array}{l}\text { Dummy variable: } 1 \text { if the } \\
\text { communitarian family type prevailed in } \\
\text { the Middle Ages, } 0 \text { otherwise }\end{array}$ & $\begin{array}{l}\text { Todd (1990), Del Panta et } \\
\text { al. (1996) }\end{array}$ \\
\hline Communal republic & & $\begin{array}{l}\text { Dummy variable: } 1 \text { if the province was } \\
\text { a Communal republic in the fourteenth } \\
\text { century, } 0 \text { otherwise }\end{array}$ & De Blasio and Nuzzo (2010) \\
\hline Signoria & & $\begin{array}{l}\text { Dummy variable: } 1 \text { if the province was } \\
\text { ruled by a Signoria in the fourteenth } \\
\text { century, } 0 \text { otherwise }\end{array}$ & De Blasio and Nuzzo (2010) \\
\hline Papal State & & $\begin{array}{l}\text { Dummy variable: } 1 \text { if the province was } \\
\text { ruled by the Pope in the fourteenth } \\
\text { century, } 0 \text { otherwise }\end{array}$ & De Blasio and Nuzzo (2010) \\
\hline Kingdom of Sicily & & $\begin{array}{l}\text { Dummy variable: } 1 \text { if the province was } \\
\text { under the Kingdom of Sicily in the } \\
\text { fourteenth century, } 0 \text { otherwise }\end{array}$ & De Blasio and Nuzzo (2010) \\
\hline Peripheral areas & & $\begin{array}{l}\text { Dummy variable: } 1 \text { if the province was } \\
\text { a peripheral area in the fourteenth } \\
\text { century, } 0 \text { otherwise }\end{array}$ & De Blasio and Nuzzo (2010) \\
\hline Height & & $\begin{array}{l}\text { Average height at age } 20 \text { of military } \\
\text { conscripts }\end{array}$ & A’Hearn et al. (2011) \\
\hline Population density & & $\begin{array}{l}\text { Total population (in thousands) living } \\
\text { in a province (at } 1871 \text { boundaries) in } \\
1861 / \text { provincial surface in squared } \\
\text { kilometers }\end{array}$ & MAIC (1864), Vigo (1971) \\
\hline Industrialization & & $\begin{array}{l}\text { Provincial index of relative } \\
\text { industrialization calculated on the basis } \\
\text { of census data as the share of industrial } \\
\text { value added, excluding construction, } \\
\text { over the share of the male population } \\
\text { over age } 15\end{array}$ & $\begin{array}{l}\text { Ciccarelli and Fenoaltea } \\
\text { (2013) }\end{array}$ \\
\hline $\begin{array}{l}\text { Number of children } \\
\text { per school }\end{array}$ & & $\begin{array}{l}\text { Number of children 6-10 in } 1870 / \\
\text { number of schools in } 1869\end{array}$ & Buonazia (1870) \\
\hline $\begin{array}{l}\text { Number of children } \\
\text { per teacher }\end{array}$ & & $\begin{array}{l}\text { Number of children 6-12/number of } \\
\text { teachers in } 1862-63\end{array}$ & MAIC (1865), Vigo (1971) \\
\hline $\begin{array}{l}\text { Number of pupils } \\
\text { per teacher }\end{array}$ & & $\begin{array}{l}\text { Number of pupils/ number of teachers } \\
\text { in } 1862-63\end{array}$ & MAIC (1865), Vigo (1971) \\
\hline $\begin{array}{l}\text { Female teachers } \\
\text { over total teachers }\end{array}$ & & $\begin{array}{l}\text { Female teachers in } 1861 / \text { total teachers } \\
\text { in } 1861 \text { in public schools }\end{array}$ & Vigo (1971) \\
\hline Town 1000 & & $\begin{array}{l}\text { Dummy variable: } 1 \text { if the province } \\
\text { included a town in year } 1000,0 \\
\text { otherwise }\end{array}$ & Bairoch et al. (1988) \\
\hline $\begin{array}{l}\text { Female to male ratio } \\
\text { literacy } 1861\end{array}$ & $\begin{array}{l}\text { Percentage of literate } \\
\text { females over female } \\
\text { population aged } 5 \text { or more } \\
\text { in } 1861 / \text { percentage of } \\
\text { literate males over male } \\
\text { population aged } 5 \text { or more } \\
\text { in } 1861=\text { Gender Parity } \\
\text { Index in literacy in } 1861 \\
\text { (range } 0-1 \text { ) }\end{array}$ & $\begin{array}{l}\text { (Female population able to read and } \\
\text { write in } 1861 / \text { female population aged } \\
5 \text { or more in } 1861) /(\text { male population } \\
\text { able to read and write in } 1861 / \text { male } \\
\text { population aged } 5 \text { or more in } 1861 \text { ) }\end{array}$ & MAIC (1864) \\
\hline
\end{tabular}




\begin{tabular}{|l|l|l|l|}
\hline Savoys & & $\begin{array}{l}\text { Dummy variable: } 1 \text { if the province was } \\
\text { ruled by the Savoy-Carignano dynasty } \\
\text { prior to Unification, 0 otherwise }\end{array}$ & Pécout (1999) \\
\hline Habsburgs & $\begin{array}{l}\text { Dummy variable: } 1 \text { if the province was } \\
\text { ruled by the Habsburg dynasty prior to } \\
\text { Unification, 0 otherwise }\end{array}$ & Pécout (1999) \\
\hline Pope & $\begin{array}{l}\text { Dummy variable: } 1 \text { if the province was } \\
\text { ruled by the Pope prior to Unification, } \\
\text { 0 otherwise }\end{array}$ & Pécout (1999) \\
\hline Bourbons & $\begin{array}{l}\text { Dummy variable: 1 if the province was } \\
\text { ruled by the Bourbon dynasty prior to } \\
\text { Unification, 0 otherwise }\end{array}$ & Pécout (1999) \\
\hline $\begin{array}{l}\text { Non weighted } \\
\text { female to male ratio } \\
\text { schooling rate }\end{array}$ & $\begin{array}{l}\text { (Female pupils enrolled in upper } \\
\text { primary schools/total number of pupils } \\
\text { enrolled in upper primary schools)/ } \\
\text { (male pupils enrolled in upper primary } \\
\text { schools/total number of pupils enrolled } \\
\text { in upper primary schools) = female } \\
\text { pupils enrolled in upper primary } \\
\text { schools/ male pupils enrolled in upper } \\
\text { primary schools }\end{array}$ & MAIC (various years) \\
\hline $\begin{array}{l}\text { Percentage of girls } \\
\text { among pupils in upper } \\
\text { primary schools }\end{array}$ & $\begin{array}{l}\text { Percentage of female pupils over the } \\
\text { total number of pupils enrolled in upper } \\
\text { primary schools }\end{array}$ & MAIC (various years) \\
\hline Abacus school & $\begin{array}{l}\text { Dummy variable: 1 if the province } \\
\text { included an abacus school up to the } \\
\text { sixteenth century, 0 otherwise }\end{array}$ & $\begin{array}{l}\text { Black (2007) and Ulivi } \\
\text { (2008) }\end{array}$ \\
\hline
\end{tabular}

\section{Methodological notes}

Medieval commerce: This variable is a dummy taking value 1 if the main city was on medieval commercial routes or was the seat of a fair or a bank in the thirteenth to fourteenth centuries, 0 otherwise. As a general rule we select the nodes of the major trade routes on the basis of two major maps of the period, as collected by Shepherd (1926) and by the atlas Atlante Storico Treccani (2007) and by crossing this information with additional evidence provided by Fanfani (1968), Luzzatto (1963), and Piccinni (1999).

In addition to that, according to our reading of Italian history, during the Middle Ages some towns were associated with particular functions that also placed them at the center of international exchange. These functions were related to the presence of an internationally known fair and/or a bank. To be noted is that the historiography locates the origins of the banking system, as a result of the larger volume of commercial activity and the increased demand for credit, in the same period under consideration.

Accordingly, inn what follows we list three groups of commercial centers notwithstanding the fact that in some cases they overlap. When the commercial center does not correspond to the main town of the corresponding province, we mention the name of the commercial center in brackets after the name of the province.

- Towns on trade routes: Novara (Vercelli), Turin, Genoa, Bergamo, Brescia, Como, Cremona, Milan, Pavia, Padua, Udine, Venice, Bologna, Ferrara, Modena, Parma, Piacenza, 
Arezzo, Florence, Pisa, Siena, Rome, Perugia, Naples, Salerno, Bari, Lecce, Catanzaro, Messina, Siracusa, Palermo, Sassari.

- International fair seats: Verona, Ferrara, Ancona (Senigallia), Salerno.

- Bank seats: Genoa, Alessandria (Asti), Turin (Chieri), Piacenza, Milan, Cremona, Pavia, Florence (Florence and Pistoia), Lucca, Siena.

Since there is no comprehensive source of information on the status of commercial centers in the Middle Ages we are aware of the possible underestimation of the number of medieval commercial hubs. Figure 1 offers a visual illustration of the pattern of commercial routes and fairs as taken from Shepherd (1926). Figure 2 highlights the location of the Italian provinces hosting a medieval commercial center.

Enrollment rates: We collect data for 1861, 1881, and 1901. Due to historical circumstances, we encountered a few problems because of lack of data in particular referring to the first wave. This arises from the fact that the Italian Unification process was a gradual process and therefore official statistical annuals could not take into account those provinces which entered the Italian Kingdom only in subsequent years. As a result data on enrollments are constructed from various sources and mainly from Statistica del Regno d'Italia, Istruzione pubblica e privata, a statistical series compiled and published by the Ministry of Agriculture, Industry and Commerce (MAIC) from 1865 to 1906, and from Vigo (1971). For most provinces for 1861 we use enrollment data referring to 1862-63. For provinces belonging to today's Veneto data on enrollments for the first wave refer to 1856 and are from Buonazia (1870) and Vigo (1971) for primary school and Sacchi (1858) for upper primary school. For Mantua data refer to 1851 and are from Vigo (1971) for primary school and from MAIC (1872) for upper primary school. For Rome (and Comarca) data refer to 1858 and are from Vigo (1971) for primary school and from MAIC (1872) for upper primary school.

To determine enrollment rates, we consider 6-12 (excluded) as the relevant primary school age. In calculating lower and upper primary enrollment rates we still employ the population 6-12 (excluded) because we have no data for the specific grade ages. Therefore at the lower and upper level we have an unadjusted measure of enrollment (Benavot and Riddle, 1988) which induces a downward bias in the measure of enrollment rates.

In some cases gross enrollment rates are greater than 100 percent and this is due to underaged and/or over-aged enrollment with respect to the school age being considered (and this is even more compelling during a period of expansion of mass education with a high incidence of late entrance). However, information on net rates (defined as the ratio between the enrollment of age 612 over the population of age 6-12) is not available.

Urban population density: We aggregate data on the total population (in thousands) living in all cities within a given province (at 1871 boundaries) in 1300 and we divide it by the provincial surface in squared kilometers. The source for population is Malanima (1998), who provides estimates of the populations of Italian cities with more than 5,000 inhabitants on a centennial basis over the period 1300-1861. 
University: We create a dummy variable that equals 1 for the presence of an ancient university or studium (in particular, law schools) between the eleventh and the thirteenth century, 0 otherwise. A good reference is Rashdall (1987).

Family types: We adapt the classification proposed by Todd (1990) to the Italian specific regional differentiation following Del Panta et al. (1996). We code provinces according to the prevailing family type in the Middle Ages and distinguish four types of families: incomplete stem, communitarian, egalitarian nuclear with delayed marriage, and egalitarian nuclear family with early marriage.

Political regimes: This set of binary dummy variables is intended to grasp the long-run effect of different local systems of government in fourteenth century's Italy. We rely on the classification given by De Blasio and Nuzzo (2010) who distinguish Italian provinces in 5 groups: the Communal republics, characterized by republicanism; the Signorie, under seignorial rule (Prince); the Papal State, characterized by a mixture of feudalism, tyranny, and republicanism; the Kingdom of Sicily, characterized by absolutism; and a residual category for those peripheral provinces which, at the beginning of the fourteenth century, were politically closer to foreign nations than to Italian local states (e.g., Sardinia and Western Piedmont).

Height: Data about wealth of ancient Italian provinces are not available. For this reason we employ height as a proxy for wealth. In the economic history literature it is common to make use of anthropometric measures because they provide important indirect information on changes in the well-being of the population. Data on height refer to the mean height of military conscripts aged 20 at the provincial level and are taken from A'Hearn et al. (2011, Table S3). For an exhaustive presentation of the use of this kind of anthropometric data as a plausible proxy for well-being and living standards see A'Hearn et al. (2011, Ch. 2). For a discussion about the methodological approach employed to estimate average height see A'Hearn et al. (2009).

Population density: We collect data about the total population living in each province in 1861 from the census (MAIC, 1864) and, for provinces belonging to Veneto, Mantua, and Rome, from Vigo (1971). We divide it by total surface of the province in squared kilometers.

Industrialization: Data on industrialization at the provincial level are taken from Ciccarelli and Fenoaltea (2013, Table 2). The variable is a provincial index of relative industrialization calculated on the basis of census data as the share of industrial value added, excluding construction, over the share of the male population over age 15. Ciccarelli and Fenoaltea (2013) explain that using this age/sex group provides the best proxy of local GDP, because adult males represented the most mobile and flexible segment of the labor force and also because male labor force participation rates are uniformly high and not clouded, as female rates are, by varying local conventions. Data for the first wave refer to 1871 . 
Ruling dynasties: This set of binary dummy variables are intended to capture the ruling dynasties immediately prior to Unification: the Savoy-Carignano, who ruled in the North Western areas of Italy, i.e., Piedmont, Liguria, and the island of Sardinia; the Habsburgs, who held direct control over Lombardy-Venetia in the North East, as part of the Austrian Empire, as well as indirect control over the Granduchy of Tuscany (Habsburg-Lorena) and other minor Duchies nearby (the Duchy of Modena under Este of Austria, the Duchy of Parma and Piacenza, and the Duchy of Massa Carrara under Habsburg-Lorena); the Pope, reigning over Rome and the Center South; and the Bourbons, in charge of the South and the Duchy of Lucca. Even though the latter falls under the Habsburgs in 1847, we consider it as dominated by the Bourbons throughout the 1816-1861 period. Information is from Pécout (1999).

Town 1000: This variable is a dummy that equals 1 for the presence of a town in year 1000 within province boundaries, i.e., for Genoa, Bergamo, Pavia, Padua, Venice, Verona, Ferrara, Pisa, Rome, Naples, Salerno, Bari, and Palermo. The information is obtained from Bairoch et al. (1988), who report the population of European cities that ever reached 5,000 inhabitants from year 800 up to year 1850, at century intervals for 800 to 1700 and half-century intervals for 1750 to 1850 . All cities reported for year 1000 actually had more than 10,000 inhabitants.

Literacy rates: Data on literacy are calculated on the basis of the 1861 Census that reports the number of people able to read or read and write aged 5 or more. Data for Veneto and Mantua refer to 1867 . They are taken from MAIC (1868) and come from wedding registers as the ability to sign one's name in full on a marriage certificate. Data for Rome refer to 1871 and come from MAIC (1906).

Table A2. Summary statistics

\begin{tabular}{|c|c|c|c|c|c|}
\hline Variable & Obs & Mean & Std. Dev. & Min & Max \\
\hline Medieval commerce & 69 & 0.522 & 0.503 & 0 & 1 \\
\hline Schooling rate & 69 & 39.468 & 24.529 & 9.746 & 107.298 \\
\hline Lower schooling rate & 69 & 36.78 & 23.62 & 8.6 & 103.689 \\
\hline Upper schooling rate & 69 & 2.642 & 2.871 & 0 & 15.944 \\
\hline Male schooling rate & 69 & 46.153 & 26.424 & 13.002 & 115.701 \\
\hline Female schooling rate & 69 & 32.305 & 25.725 & 3.767 & 107.072 \\
\hline Female to male ratio schooling rate & 69 & 0.705 & 0.288 & 0.059 & 1.516 \\
\hline Female to male ratio upper schooling rate & 69 & 0.316 & 0.29 & 0 & 1.323 \\
\hline Female to male ratio lower schooling rate & 69 & 0.724 & 0.292 & 0.046 & 1.339 \\
\hline Masculinity index & 69 & 1.04 & 0.031 & 0.949 & 1.122 \\
\hline Latitude & 69 & 42.692 & 2.622 & 37.04 & 46.11 \\
\hline Longitude & 69 & 11.971 & 2.471 & 7.33 & 18.11 \\
\hline Sea & 69 & 0.58 & 0.497 & 0 & 1 \\
\hline River & 69 & 0.406 & 0.495 & 0 & 1 \\
\hline Plain & 69 & 1.058 & 0.662 & 0 & 2 \\
\hline Urban population density & 69 & 0.01 & 0.011 & 0 & 0.06 \\
\hline University & 69 & 0.391 & 0.492 & 0 & 1 \\
\hline Egalitarian nuclear family with early marriage & 69 & 0.304 & 0.464 & 0 & 1 \\
\hline
\end{tabular}




\begin{tabular}{lccccc}
\hline Egalitarian nuclear family with delayed marriage & 69 & 0.232 & 0.423 & 0 & 1 \\
Incomplete stem family & 69 & 0.130 & 0.339 & 0 & 1 \\
Communitarian family & 69 & 0.333 & 0.475 & 0 & 1 \\
Communal republic & 69 & 0.261 & 0.442 & 0 & 1 \\
Signoria & 69 & 0.246 & 0.434 & 0 & 1 \\
Papal State & 69 & 0.101 & 0.304 & 0 & 1 \\
Kingdom of Sicily & 69 & 0.333 & 0.475 & 0 & 1 \\
Peripheral areas & 69 & 0.058 & 0.235 & 0 & 1 \\
Height & 69 & 162.394 & 2.029 & 158.1 & 165.9 \\
Population density & 69 & 108.633 & 92.55 & 18.595 & 741.15 \\
Industrialization & 69 & 0.934 & 0.292 & 0.48 & 1.69 \\
Number of children per school & 69 & 92.50866 & 56.28147 & 24.82081 & 427.0714 \\
Number of children per teacher & 69 & 110.5569 & 67.05568 & 32.08353 & 354.2019 \\
Number of pupils per teacher & 69 & 32.90421 & 9.390294 & 16.68564 & 55.29586 \\
Female teachers over total teachers & 69 & 34.897 & 12.574 & 2.429 & 60.5 \\
Town 1000 & 69 & 0.188 & 0.394 & 0 & 1 \\
Literacy & 69 & 23.452 & 13.151 & 8.429 & 58.675 \\
Male literacy & 69 & 30.335 & 14.428 & 13.194 & 67.139 \\
Female literacy & 69 & 16.582 & 12.448 & 3.028 & 50.956 \\
Female to male ratio literacy & 69 & 0.493 & 0.185 & 0.185 & 0.892 \\
Savoys & 69 & 0.116 & 0.323 & 0 & 1 \\
Habsburgs & 69 & 0.391 & 0.492 & 0 & 1 \\
Pope & 69 & 0.174 & 0.382 & 0 & 1 \\
Bourbons & 69 & 0.319 & 0.469 & 0 & 1 \\
Non-weighted female to male ratio schooling rate & 69 & 0.305 & 0.281 & 0 & 1.288 \\
Percentage of girls among pupils in upper primary schools & 69 & 20.437 & 15.292 & 0 & 56.292 \\
Abacus school & 69 & 0.246 & 0.434 & 0 & 1 \\
\hline & & & & & 0 \\
\hline
\end{tabular}


Table A3: Robustness checks

\begin{tabular}{|c|c|c|c|c|c|c|c|c|c|c|c|c|c|c|}
\hline & (1) & $(2)$ & (3) & $(4)$ & (5) & (6) & (7) & $(8)$ & (9) & $(10)$ & (11) & (12) & (13) & (14) \\
\hline & $\begin{array}{l}\text { Female to } \\
\text { male ratio } \\
\text { upper } \\
\text { primary } \\
\text { schooling } \\
\text { rate }\end{array}$ & $\begin{array}{l}\text { Female to } \\
\text { male ratio } \\
\text { upper } \\
\text { primary } \\
\text { schooling } \\
\text { rate }\end{array}$ & $\begin{array}{l}\text { Female to } \\
\text { male ratio } \\
\text { upper } \\
\text { primary } \\
\text { schooling } \\
\text { rate }\end{array}$ & $\begin{array}{l}\text { Female to } \\
\text { male ratio } \\
\text { upper } \\
\text { primary } \\
\text { schooling } \\
\text { rate }\end{array}$ & $\begin{array}{l}\text { Female to } \\
\text { male ratio } \\
\text { upper } \\
\text { primary } \\
\text { schooling } \\
\text { rate }\end{array}$ & $\begin{array}{l}\text { Female to } \\
\text { male ratio } \\
\text { upper } \\
\text { primary } \\
\text { schooling } \\
\text { rate }\end{array}$ & $\begin{array}{l}\text { Female to } \\
\text { male ratio } \\
\text { upper } \\
\text { primary } \\
\text { schooling } \\
\text { rate }\end{array}$ & $\begin{array}{c}\text { Female to } \\
\text { male ratio } \\
\text { upper } \\
\text { primary } \\
\text { schooling } \\
\text { rate }\end{array}$ & $\begin{array}{c}\text { Non } \\
\text { weighted } \\
\text { female to } \\
\text { male } \\
\text { schooling } \\
\text { ratio }\end{array}$ & $\begin{array}{c}\text { Non } \\
\text { weighted } \\
\text { female to } \\
\text { male } \\
\text { schooling } \\
\text { ratio }\end{array}$ & $\begin{array}{l}\% \text { Girls } \\
\text { among } \\
\text { pupils in } \\
\text { upper } \\
\text { primary } \\
\text { schools }\end{array}$ & $\begin{array}{l}\text { Female to } \\
\text { male ratio } \\
\text { upper } \\
\text { primary } \\
\text { schooling } \\
\text { rate }\end{array}$ & $\begin{array}{l}\text { Female to } \\
\text { male ratio } \\
\text { upper } \\
\text { primary } \\
\text { schooling } \\
\text { rate }\end{array}$ & $\begin{array}{c}\text { Female to } \\
\text { male ratio } \\
\text { upper } \\
\text { primary } \\
\text { schooling } \\
\text { rate }\end{array}$ \\
\hline & OLS & OLS & OLS & OLS & $\begin{array}{c}\text { Spatial } \\
\text { error model }\end{array}$ & OLS & OLS & OLS & OLS & OLS & OLS & OLS & OLS & OLS \\
\hline Medieval commerce & $\begin{array}{c}0.146^{* *} \\
(0.072)\end{array}$ & $\begin{array}{c}0.166^{* *} \\
(0.072)\end{array}$ & $\begin{array}{c}0.164 * * \\
(0.074)\end{array}$ & $\begin{array}{c}0.164 * * * \\
(0.040)\end{array}$ & $\begin{array}{c}0.200^{* * *} \\
(0.072)\end{array}$ & $\begin{array}{c}0.159 * * \\
(0.065)\end{array}$ & $\begin{array}{c}0.193 * * * \\
(0.068)\end{array}$ & $\begin{array}{c}0.157 * * \\
(0.074)\end{array}$ & $\begin{array}{c}0.153 * * \\
(0.064)\end{array}$ & $\begin{array}{c}0.144^{* *} \\
(0.060)\end{array}$ & $\begin{array}{l}6.741 * \\
(3.657)\end{array}$ & $\begin{array}{c}0.183 * * \\
(0.078)\end{array}$ & $\begin{array}{c}0.150 * * \\
(0.073)\end{array}$ & $\begin{array}{c}0.120^{* * *} \\
(0.055)\end{array}$ \\
\hline Latitude & $\begin{array}{c}0.020 \\
(0.034)\end{array}$ & $\begin{array}{l}0.0210 \\
(0.024)\end{array}$ & $\begin{array}{c}0.020 \\
(0.020)\end{array}$ & $\begin{array}{c}0.020 \\
(0.020)\end{array}$ & $\begin{array}{c}0.020 \\
(0.025)\end{array}$ & $\begin{array}{c}0.030 \\
(0.033)\end{array}$ & $\begin{array}{l}-0.050 \\
(0.077)\end{array}$ & $\begin{array}{c}0.030 \\
(0.032)\end{array}$ & $\begin{array}{c}0.020 \\
(0.033)\end{array}$ & $\begin{array}{c}0.020 \\
(0.034)\end{array}$ & $\begin{array}{c}1.420 \\
(1.771)\end{array}$ & $\begin{array}{c}0.002 \\
(0.036)\end{array}$ & $\begin{array}{c}0.002 \\
(0.038)\end{array}$ & $\begin{array}{l}0.046^{*} \\
(0.025)\end{array}$ \\
\hline Longitude & $\begin{array}{l}-0.024 \\
(0.038)\end{array}$ & $\begin{array}{l}-0.026 \\
(0.031)\end{array}$ & $\begin{array}{l}-0.025 \\
(0.033)\end{array}$ & $\begin{array}{l}-0.025 \\
(0.014)\end{array}$ & $\begin{array}{l}-0.030 \\
(0.028)\end{array}$ & $\begin{array}{l}-0.015 \\
(0.038)\end{array}$ & $\begin{array}{c}-0.048 \\
(0.044)\end{array}$ & $\begin{array}{l}-0.026 \\
(0.040)\end{array}$ & $\begin{array}{l}-0.025 \\
(0.036)\end{array}$ & $\begin{array}{l}-0.0315 \\
(0.040)\end{array}$ & $\begin{array}{l}-2.491 \\
(2.011)\end{array}$ & $\begin{array}{l}-0.004 \\
(0.040)\end{array}$ & $\begin{array}{l}-0.006 \\
(0.041)\end{array}$ & $\begin{array}{c}-0.059 * * \\
(0.027)\end{array}$ \\
\hline Sea & $\begin{array}{l}-0.043 \\
(0.088)\end{array}$ & $\begin{array}{l}-0.064 \\
(0.089)\end{array}$ & $\begin{array}{l}-0.050 \\
(0.105)\end{array}$ & $\begin{array}{l}-0.050 \\
(0.102)\end{array}$ & $\begin{array}{l}-0.134 \\
(0.120)\end{array}$ & $\begin{array}{l}-0.035 \\
(0.085)\end{array}$ & $\begin{array}{l}-0.021 \\
(0.108)\end{array}$ & $\begin{array}{l}-0.002 \\
(0.073)\end{array}$ & $\begin{array}{l}-0.045 \\
(0.082)\end{array}$ & $\begin{array}{l}-0.024 \\
(0.093)\end{array}$ & $\begin{array}{l}-0.111 \\
(4.261)\end{array}$ & $\begin{array}{l}-0.103 \\
(0.108)\end{array}$ & $\begin{array}{l}-0.090 \\
(0.089)\end{array}$ & $\begin{array}{c}0.039 \\
(0.053)\end{array}$ \\
\hline River & $\begin{array}{c}0.032 \\
(0.080)\end{array}$ & $\begin{array}{l}-0.005 \\
(0.077)\end{array}$ & $\begin{array}{c}0.019 \\
(0.042)\end{array}$ & $\begin{array}{c}0.019 \\
(0.056)\end{array}$ & $\begin{array}{l}-0.038 \\
(0.082)\end{array}$ & $\begin{array}{l}-0.033 \\
(0.085)\end{array}$ & $\begin{array}{l}-0.047 \\
(0.085)\end{array}$ & $\begin{array}{c}0.020 \\
(0.081)\end{array}$ & $\begin{array}{c}0.023 \\
(0.081)\end{array}$ & $\begin{array}{c}0.042 \\
(0.079)\end{array}$ & $\begin{array}{c}2.403 \\
(4.245)\end{array}$ & $\begin{array}{l}-0.052 \\
(0.099)\end{array}$ & $\begin{array}{c}0.032 \\
(0.093)\end{array}$ & $\begin{array}{l}-0.053 \\
(0.062)\end{array}$ \\
\hline Plain & $\begin{array}{l}-0.063 \\
(0.055)\end{array}$ & $\begin{array}{l}-0.063 \\
(0.057)\end{array}$ & $\begin{array}{c}-0.057^{*} \\
(0.031)\end{array}$ & $\begin{array}{c}-0.057^{* *} \\
(0.022)\end{array}$ & $\begin{array}{l}-0.064 \\
(0.046)\end{array}$ & $\begin{array}{l}-0.028 \\
(0.068)\end{array}$ & $\begin{array}{l}-0.070 \\
(0.093)\end{array}$ & $\begin{array}{l}-0.034 \\
(0.055)\end{array}$ & $\begin{array}{l}-0.053 \\
(0.055)\end{array}$ & $\begin{array}{l}-0.051 \\
(0.055)\end{array}$ & $\begin{array}{l}-1.198 \\
(2.726)\end{array}$ & $\begin{array}{l}-0.057 \\
(0.066)\end{array}$ & $\begin{array}{l}-0.065 \\
(0.062)\end{array}$ & $\begin{array}{l}-0.002 \\
(0.041)\end{array}$ \\
\hline $\begin{array}{l}\text { Urban population } \\
\text { density }\end{array}$ & & 0.325 & -0.264 & -0.264 & 0.0889 & -2.300 & -1.709 & -0.282 & -0.102 & 1.091 & 131.5 & -3.209 & 0.930 & 1.052 \\
\hline University & $\begin{array}{c}0.008 \\
(0.066)\end{array}$ & $\begin{array}{l}(3.489) \\
-0.002 \\
(0.069)\end{array}$ & $\begin{array}{c}(3.433) \\
0.016 \\
(0.050)\end{array}$ & $\begin{array}{c}(2.695) \\
0.016 \\
(0.049)\end{array}$ & $\begin{array}{l}(2.872) \\
-0.031 \\
(0.084)\end{array}$ & $\begin{array}{c}(3.817) \\
0.065 \\
(0.066)\end{array}$ & $\begin{array}{c}(4.292) \\
0.102 \\
(0.063)\end{array}$ & $\begin{array}{c}(3.092) \\
0.038 \\
(0.061)\end{array}$ & $\begin{array}{c}(3.004) \\
0.021 \\
(0.065)\end{array}$ & $\begin{array}{c}(2.895) \\
0.042 \\
(0.065)\end{array}$ & $\begin{array}{c}(164.9) \\
2.220 \\
(4.099)\end{array}$ & $\begin{array}{c}(3.801) \\
0.030 \\
(0.083)\end{array}$ & $\begin{array}{c}(3.279) \\
-0.002 \\
(0.072)\end{array}$ & $\begin{array}{c}(2.562) \\
0.065 \\
(0.051)\end{array}$ \\
\hline $\begin{array}{l}\text { Egalitarian nuclear } \\
\text { family early marriage }\end{array}$ & $\begin{array}{c}0.130 \\
(0.221)\end{array}$ & $\begin{array}{c}0.206 \\
(0.223)\end{array}$ & $\begin{array}{c}0.132 \\
(0.220)\end{array}$ & $\begin{array}{c}0.132 \\
(0.139)\end{array}$ & $\begin{array}{c}0.212 \\
(0.185)\end{array}$ & $\begin{array}{l}0.393 * \\
(0.213)\end{array}$ & $\begin{array}{l}-0.135 \\
(0.208)\end{array}$ & $\begin{array}{c}0.211 \\
(0.253)\end{array}$ & $\begin{array}{c}0.098 \\
(0.215)\end{array}$ & $\begin{array}{c}0.005 \\
(0.207)\end{array}$ & $\begin{array}{c}6.116 \\
(11.42)\end{array}$ & $\begin{array}{l}-0.040 \\
(0.240)\end{array}$ & $\begin{array}{l}-0.030 \\
(0.225)\end{array}$ & $\begin{array}{c}0.276 \\
(0.202)\end{array}$ \\
\hline $\begin{array}{l}\text { Incomplete stem } \\
\text { family }\end{array}$ & $\begin{array}{l}-0.167 \\
(0.139)\end{array}$ & $\begin{array}{l}-0.210^{*} \\
(0.121)\end{array}$ & $\begin{array}{l}-0.163 \\
(0.091)\end{array}$ & $\begin{array}{c}-0.163^{* *} \\
(0.045)\end{array}$ & $\begin{array}{l}-0.129 \\
(0.114)\end{array}$ & $\begin{array}{l}0.0715 \\
(0.139)\end{array}$ & $\begin{array}{l}-0.0191 \\
(0.122)\end{array}$ & $\begin{array}{l}-0.208 \\
(0.171)\end{array}$ & $\begin{array}{l}-0.179 \\
(0.137)\end{array}$ & $\begin{array}{l}-0.244 \\
(0.150)\end{array}$ & $\begin{array}{l}-8.030 \\
(10.97)\end{array}$ & & $\begin{array}{l}-0.199 \\
(0.147)\end{array}$ & $\begin{array}{l}-0.100 \\
(0.122)\end{array}$ \\
\hline $\begin{array}{l}\text { Communitarian } \\
\text { family }\end{array}$ & -0.111 & -0.116 & -0.111 & $-0.111^{*}$ & -0.090 & 0.131 & $-0.317 * *$ & -0.116 & -0.132 & -0.202 & -7.942 & -0.163 & -0.122 & -0.065 \\
\hline Communal republic & $\begin{array}{l}(0.136) \\
-0.026 \\
(0.108)\end{array}$ & $\begin{array}{l}(0.138) \\
-0.036 \\
(0.115)\end{array}$ & $\begin{array}{l}(0.110) \\
-0.016 \\
(0.093)\end{array}$ & $\begin{array}{c}(0.0455) \\
-0.016 \\
(0.072)\end{array}$ & $\begin{array}{c}(0.106) \\
0.025 \\
(0.105)\end{array}$ & $\begin{array}{l}(0.145) \\
-0.029 \\
(0.089)\end{array}$ & $\begin{array}{c}(0.139) \\
-0.064 \\
(0.113)\end{array}$ & $(0.162)$ & $\begin{array}{c}(0.132) \\
-0.019 \\
(0.104)\end{array}$ & $\begin{array}{l}(0.138) \\
-0.032 \\
(0.110)\end{array}$ & $\begin{array}{l}(8.184) \\
-2.754 \\
(5.749)\end{array}$ & $\begin{array}{l}(0.159) \\
-0.055 \\
(0.169)\end{array}$ & $\begin{array}{l}(0.140) \\
-0.011 \\
(0.111)\end{array}$ & $\begin{array}{l}(0.120) \\
-0.064 \\
(0.080)\end{array}$ \\
\hline Papal state & $\begin{array}{l}-0.070 \\
(0.159)\end{array}$ & $\begin{array}{l}-0.031 \\
(0.159)\end{array}$ & $\begin{array}{l}-0.036 \\
(0.134)\end{array}$ & $\begin{array}{l}-0.036 \\
(0.0483)\end{array}$ & $\begin{array}{c}0.043 \\
(0.149)\end{array}$ & $\begin{array}{l}-0.091 \\
(0.152)\end{array}$ & $\begin{array}{c}-0.294 * * \\
(0.138)\end{array}$ & & $\begin{array}{l}-0.036 \\
(0.148)\end{array}$ & $\begin{array}{l}-0.043 \\
(0.146)\end{array}$ & $\begin{array}{l}-2.746 \\
(8.077)\end{array}$ & $\begin{array}{l}-0.105 \\
(0.175)\end{array}$ & $\begin{array}{l}-0.136 \\
(0.163)\end{array}$ & $\begin{array}{c}0.013 \\
(0.145)\end{array}$ \\
\hline Kingdom of Sicily & $-0.427 * *$ & $-0.458 * *$ & $-0.417 * *$ & $-0.417^{*}$ & $-0.459 * * *$ & $-0.673 * *$ & -0.407 & & $-0.374 * *$ & -0.253 & -16.12 & $-0.421^{*}$ & $-0.425^{* *}$ & -0.287 \\
\hline
\end{tabular}




\begin{tabular}{|c|c|c|c|c|c|c|c|c|c|c|c|c|c|c|}
\hline & $(0.188)$ & $(0.215)$ & $(0.169)$ & $(0.210)$ & $(0.155)$ & $(0.269)$ & $(0.552)$ & & $(0.180)$ & $(0.224)$ & (12.12) & $(0.210)$ & $(0.189)$ & $(0.171)$ \\
\hline Peripheral areas & -0.151 & -0.105 & -0.156 & -0.156 & -0.132 & $\begin{array}{l}-0.119 \\
(0.096)\end{array}$ & -0.055 & & -0.151 & -0.161 & -6.869 & -0.132 & -0.178 & -0.119 \\
\hline & $\begin{array}{l}(0.102) \\
-0.028\end{array}$ & $(0.111)$ & $\begin{array}{l}(0.103) \\
-0.0309\end{array}$ & $\begin{array}{l}(0.090) \\
-0.031\end{array}$ & $\begin{array}{l}(0.088) \\
-0.039\end{array}$ & $\begin{array}{l}(0.096) \\
-0.017\end{array}$ & $\begin{array}{l}(0.121) \\
-0.0005\end{array}$ & & $\begin{array}{l}(0.010) \\
-0.029\end{array}$ & $\begin{array}{l}(0.104) \\
-0.022\end{array}$ & $\begin{array}{l}(5.155) \\
-1390\end{array}$ & $\begin{array}{l}(0.119) \\
-0.004\end{array}$ & $\begin{array}{l}(0.132) \\
-0.0250\end{array}$ & $\begin{array}{l}(0.083) \\
-0.0426\end{array}$ \\
\hline Height & $\begin{array}{c}-0.028 \\
(0.0313)\end{array}$ & & $\begin{array}{l}-0.0309 \\
(0.0234)\end{array}$ & $\begin{array}{l}-0.031 \\
(0.025)\end{array}$ & $\begin{array}{c}-0.039 \\
(0.0273)\end{array}$ & $\begin{array}{c}-0.017 \\
(0.0395)\end{array}$ & $\begin{array}{c}-0.0005 \\
(0.046)\end{array}$ & $\begin{array}{l}-0.033 \\
(0.035)\end{array}$ & $\begin{array}{c}-0.029 \\
(0.0304)\end{array}$ & $\begin{array}{l}-0.022 \\
(0.030)\end{array}$ & $\begin{array}{l}-1.390 \\
(1.768)\end{array}$ & $\begin{array}{l}-0.004 \\
(0.036)\end{array}$ & $\begin{array}{c}-0.0250 \\
(0.033)\end{array}$ & $\begin{array}{l}-0.0426 \\
(0.026)\end{array}$ \\
\hline Population density & $\begin{array}{c}0.0003 \\
(0.0002)\end{array}$ & $\begin{array}{c}0.0003 \\
(0.0003)\end{array}$ & $\begin{array}{c}0.0003 \\
(0.0003)\end{array}$ & $\begin{array}{c}0.0003 \\
(0.0003)\end{array}$ & $\begin{array}{l}0.0004 * \\
(0.0003)\end{array}$ & $\begin{array}{c}0.0004 \\
(0.0003)\end{array}$ & $\begin{array}{l}9.94 \mathrm{e}-05 \\
(0.0004)\end{array}$ & $\begin{array}{c}0.0003 \\
(0.0002)\end{array}$ & $\begin{array}{c}0.0002 \\
(0.0002)\end{array}$ & $\begin{array}{l}7.49 \mathrm{e}-05 \\
(0.0003)\end{array}$ & $\begin{array}{c}0.009 \\
(0.015)\end{array}$ & $\begin{array}{c}0.0006^{* *} \\
(0.0003)\end{array}$ & $\begin{array}{c}0.0003 \\
(0.0002)\end{array}$ & $\begin{array}{c}0.0002 \\
(0.0002)\end{array}$ \\
\hline Industrialization & $\begin{array}{l}-0.162 \\
(0.121)\end{array}$ & $\begin{array}{l}-0.154 \\
(0.120)\end{array}$ & $\begin{array}{l}-0.141 \\
(0.163)\end{array}$ & $\begin{array}{l}-0.141 \\
(0.187)\end{array}$ & $\begin{array}{l}-0.164 \\
(0.113)\end{array}$ & $\begin{array}{l}-0.168 \\
(0.144)\end{array}$ & $\begin{array}{l}-0.188 \\
(0.143)\end{array}$ & $\begin{array}{l}-0.140 \\
(0.128)\end{array}$ & $\begin{array}{l}-0.124 \\
(0.122)\end{array}$ & $\begin{array}{l}-0.104 \\
(0.130)\end{array}$ & $\begin{array}{l}-7.675 \\
(6.567)\end{array}$ & $\begin{array}{l}-0.205 \\
(0.132)\end{array}$ & $\begin{array}{l}-0.136 \\
(0.139)\end{array}$ & $\begin{array}{l}-0.135 \\
(0.093)\end{array}$ \\
\hline City size 1300 & $\begin{array}{c}0.001 \\
(0.001)\end{array}$ & & & & & & & & & & & & & \\
\hline $\begin{array}{l}\text { Per capita value } \\
\text { added }\end{array}$ & & $\begin{array}{l}-0.002 \\
(0.001)\end{array}$ & & & & & & & & & & & & \\
\hline Northeast & & & & & & $\begin{array}{c}-0.413^{* * *} \\
(0.148)\end{array}$ & & & & & & & & \\
\hline Center & & & & & & $\begin{array}{l}-0.229 \\
(0.151)\end{array}$ & & & & & & & & \\
\hline South & & & & & & $\begin{array}{c}-0.0371 \\
(0.197)\end{array}$ & & & & & & & & \\
\hline Pope & & & & & & & & $\begin{array}{l}-0.004 \\
(0.245)\end{array}$ & & & & & & \\
\hline Habsburgs & & & & & & & & $\begin{array}{l}0.076 \\
(0.156)\end{array}$ & & & & & & \\
\hline Bourbons & & & & & & & & $\begin{array}{l}-0.362 \\
(0.288)\end{array}$ & & & & & & \\
\hline Masculinity index & & & & & & & & & & $\begin{array}{c}1.500 \\
(1.311)\end{array}$ & $\begin{array}{c}70.77 \\
(79.89)\end{array}$ & & & \\
\hline Lambda & & & & & $\begin{array}{l}-1.273 \\
(1.011)\end{array}$ & & & & & & & & & \\
\hline $\begin{array}{l}\text { District dummies } \\
\text { Observations }\end{array}$ & 69 & 69 & 69 & 69 & & 69 & $\begin{array}{l}\text { Yes } \\
69\end{array}$ & 69 & 69 & 69 & 69 & 59 & 66 & 67 \\
\hline R-squared & 0.56 & 0.57 & 0.56 & 0.56 & & 0.60 & 0.64 & 0.55 & 0.57 & 0.58 & 0.63 & 0.58 & 0.55 & 0.66 \\
\hline Adj. R-squared & 0.40 & 0.41 & 0.40 & 0.40 & & 0.43 & 0.39 & 0.39 & 0.42 & 0.42 & 0.48 & 0.40 & 0.38 & 0.53 \\
\hline $\begin{array}{l}\text { Wald test of } \\
\text { lambda }=0 \text { : }\end{array}$ & & & & & $\begin{array}{c}\operatorname{chi} 2(1)= \\
1.587 \\
(0.208)\end{array}$ & & & & & & & & & \\
\hline $\begin{array}{l}\text { Lagrange multiplier } \\
\text { test of lambda }=0\end{array}$ & & & & & $\begin{array}{c}\operatorname{chi} 2(1)= \\
0.672 \\
(0.412)\end{array}$ & & & & & & & & & \\
\hline Variance ratio & & & & & 0.63 & & & & & & & & & \\
\hline Squared corr. & & & & & 0.54 & & & & & & & & & \\
\hline
\end{tabular}

